\title{
PERFORMANCE PRICING COVENANTS AND CORPORATE LOAN SPREADS
}

\author{
Kamphol Panyagometh ${ }^{\mathrm{a}}$, Gordon S. Roberts ${ }^{\mathrm{b},{ }^{*}}$, Aron A. Gottesman ${ }^{\mathrm{c}}$, Mehdi Beyhaghi $^{\mathrm{d}}$
}

This Version: April 2013

\begin{abstract}
We explore the relation between corporate loan spreads and performance pricing covenants (PPCs) which automatically adjust interest-rate spreads to reflect borrower's subsequent performance. We pioneer separate measurement of the impact of performance pricing depending on whether it is based on accounting ratios such as debt-to-EBITDA or on the borrower's debt rating. Applying a matched-pairs technique holding borrower and lending syndicate constant, we find that over $90 \%$ of PPCs are accounting-based and for this sub-sample the average spread reduction is 51.9 basis points. In contrast, debt-rating-based PPCs result in spreads that are only 14.6 basis points lower a difference that is only weakly statistically significant. We distinguish between interest-increasing and decreasing PPCs. Identifying the latter as a tight covenant in the covenant signaling framework of Demiroglu and James (2010), we show that such covenants are associated with higher ex post performance and a positive stock price reaction to loan announcements.
\end{abstract}

JEL classification: G21; G32

Keywords: Covenants, Performance pricing, Loan pricing

The authors received helpful comments from Andy Naranjo and from audiences at Concordia University and the Financial Management Association 2011 European Conference. Rucha Desmukh, Amit Soni and Jie Zhu furnished excellent research assistance. The Social Sciences and Humanities Research Council provided financial support for this research.

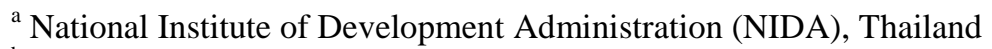

${ }^{\mathrm{b}}$ Schulich School of Business, York University, Canada

${ }^{\mathrm{c}}$ Lubin School of Business, Pace University, USA

${ }^{\mathrm{d}}$ College of Business, University of Texas at San Antonio, USA

* Corresponding author. Tel.:+1 (416) 736-2100 ext. 77953; Fax: +1 (416) 736-5687.

E-mail addresses: kpanyago@ schulich.yorku.ca (K. Panyagometh), groberts@ schulich.yorku.ca (G.S. Roberts), agottesman@pace.edu (A.A. Gottesman), mbeyhaghi@schulich.yorku.ca (M. Beyhaghi). 


\section{Performance Pricing Covenants and Corporate Loan Spreads}

\section{Introduction}

Performance pricing covenants (PPCs) in bank loans specify automatic adjustments to the interest-rate spread based on the borrower's subsequent performance as gauged by either accounting-based measures, such as the debt-to-EBITDA ratio, or debt-ratings-based performance measures, such as the Moody's or Standard \& Poor's rating of the borrower's bonds or commercial paper. Prior research identifies several ways in which PPCs could add value in alleviating market frictions: reduced transactions costs (Asquith, Beatty and Weber, 2005) and control of the agency costs of asset substitution (Bhanot and Melo, 2006; Manso, Strulovici and Tshistyi, 2010 and Koziol and Lawrenz, 2010). In addition, as an innovation in covenant design, the inclusion of a PPC in a loan agreement represents a signal to resolve asymmetric information between borrower and lender and provides an opportunity for further testing of the covenant signaling hypothesis developed by Gerleanu and Zwiebel (2006) and Demiroglu and James (2010).

The central task of this paper is to reexamine how the introduction of a performance pricing covenant influences loan spreads in the presence of covenant signaling and to explore the impact on loan announcement returns and ex post performance of the borrower. In a close antecedent to our work on spreads, Asquith, Beatty and Weber (2005) employ a joint model of the decision to introduce performance pricing and the LIBOR spread. We extend their theoretical rationale for distinguishing between interest-increasing performance pricing which specifies higher spreads should borrower credit quality decline and interest-decreasing which provides for narrower spreads should credit quality improve. Asquith et al. argue that because the creditadjustment option in an interest-increasing PPC has value to the lender, the bank must 
compensate borrowers with a lower rate and their tests support this argument. Similarly, we find that interest-increasing PPCs are associated with spreads that are 24 basis points lower in our marginal effects analysis. For interest-decreasing PPCs, Asquith et al. note that the creditadjustment option benefits borrowers by allowing those with improved credit quality to enjoy lower rates automatically. Since borrowers must pay for this potentially beneficial option, they predict and find that interest-decreasing PPCs are associated with higher spreads. Extending their discussion, in addition to the credit-adjustment option, our paper also recognizes the role of performance pricing covenants as providing a signal of borrower quality. Since such a signal has a predicted negative impact on spreads, it works in the opposite direction to the credit adjustment option in the case of interest-decreasing PPC. As a result, our extension of Asquith et al. suggests that the spread impact of this class of PPC will be either positive or negative and smaller than for interest- increasing. Our marginal effects tests support the former case revealing higher spreads by 10 - 15 basis points.

In conducting our tests on spreads we introduce two innovations that further distinguish our tests from those of Asquith et al. (2005). First, we pioneer separate measurement of the impact of performance pricing depending on whether it is accounting or debt-rating based. This distinction matters because (as shown by Doyle (2003) and reconfirmed in our tests) firms with accounting-based measures are riskier (have higher initial spreads and greater volatility of credit risk during the loan's life), borrow at longer maturities, are smaller, and are more likely to secure loans. As a result, we hypothesize that performance pricing (whether interest-increasing or decreasing) should have a greater impact on the initial spread when it is accounting based.

Second, we use matched pairs methodology and take advantage of a natural experiment to control for self-selection bias that likely arises because firm risk characteristics influence the 
decision to introduce performance pricing as well as the selection of design features: interestincreasing or decreasing, accounting or debt-rating-based. The natural experiment arises from the common practice of structuring loan deals consisting of multiple loan facilities issued on the same day with a common lead bank and set of participant lenders. Since some of the facilities in a loan deal contain a PPC and others do not, we can compare the impact of the PPC while holding borrower and lender characteristics constant. In employing matching techniques, we follow earlier papers in the literature such as Helwege and Turner (1999), Bharath (2002), and Gottesman and Roberts (2004 and 2007), among others.

Our matching methodology offers a valuable alternative lens for viewing PPC along with the potential to sharpen the focus of the study by Asquith et al. In particular, while they control for the self-selection that may be introduced by the propensity to establish either interestincreasing or interest decreasing performance pricing, such controls may be incomplete. Further, they do not recognize any differences between accounting and debt-rating based features and their sample includes both. As a result, differences in risk unobservable to the econometrician may persist. Should such risk differences be correlated with the choice of covenant type, they may lead to biased results.

Our study uses the Loan Pricing Corporation DealScan database of loans initiated from January 1, 1994 to January 1, 2010. Our pooled sample tests reveal that the presence of a PPC of any type results in spreads that are 65.66 basis points lower than they would be without the PPC. Similarly to prior studies, we also find that, as suggested by the covenant signaling hypothesis, borrowers with PPCs are less risky with higher ratings and Z-scores and take out larger loans.

Applying our matching technique we find that in its more refined control setting, the presence of any PPC is associated with a reduction in spread of 47.7 basis points. Of the 1,476 
matched pairs in our sample, 1,310 include an accounting-based PPC. For this set of pairs, the average spread is 51.9 basis points lower with the PPC. In contrast, debt-rating-based PPCs result in spreads that are only 14.6 basis points lower than they would be without the PPC, a difference that is only weakly statistically significant. We conclude that the rate spread benefits associated with PPCs are mainly limited to accounting-based-PPCs. For interest-increasing PPCs, the credit adjustment option benefiting the lender is associated with a spread reduction of 70.2 basis points in our matched pairs tests and a more modest but significant lowering by 24 basis points in our marginal effects analysis.

In the covenant signaling framework of Demiroglu and James (2010) borrowers have private information and by accepting loan terms with tight covenants, the borrower signals that it believes its financial state will improve. Consistent with this covenant-signaling hypothesis, they find that firms with tight covenants display stronger future operating performance and that announcements of loans to such firms have higher than average positive stock market reaction. In a similar vein, Manso et al. (2010) develop a theoretical model in which the rationale for performance pricing covenants lies in reducing information asymmetry about the future prospects of borrowers. ${ }^{1}$ In support of this prediction, their empirical tests reveal that borrowers with any type of performance pricing have a higher probability of a future bond rating upgrade and higher future returns on assets in contrast to borrowers without this provision in their loan agreements.

The covenant signaling framework of Demiroglu and James (2010) allows us to refine the tests in Manso et al. by tailoring our predictions more precisely to the form of performance pricing in place. In that context, interest-decreasing performance pricing is generally a tighter

\footnotetext{
${ }^{1}$ Bhanot and Melo (2006) similarly conclude that performance pricing covenants are inefficient at controlling asset substitution. In the model of Koziol and Lawrenz (2010), both asset substitution and signaling motivate the use of performance pricing.
} 
covenant than its interest-increasing counterpart. We illustrate the distinction with a hypothetical example of a company that is borrowing at LIBOR plus 100 basis points and currently has a debt/EBITDA ratio of three. ${ }^{2}$ Using an interest-increasing, accounting-based PPC, the company would agree to increase its spread to 125 basis point should debt / EBITDA rise to 3.5 and to 150 basis points for a ratio of 4.0. Beyond debt/EBITDA of 4.5, the loan becomes due on demand. This is a relaxed covenant as it gives the company slack should its debt ratio deteriorate. In contrast, with a tight covenant: borrowing at LIBOR as before, the company would now agree that the loan becomes due on demand if its debt/EBITDA ratio should rise to 3.5. Further interest-reducing provisions would state that the spread would narrow to 75 basis points if the ratio falls to 2.5 and to 50 basis points for a ratio of two. Reinforcing the generality of our example, Adam and Streitz (2013) document that interest-decreasing PPC is associated with tighter debt/EBITDA covenants. ${ }^{3}$

The tighter covenant package consisting of a lower same-variable covenant provision and an interest-decreasing PPC constitutes a signal that the firm expects its financial strength to improve. Such signals are quite common: we find that interest-decreasing PPC is roughly twice as prevalent as interest-increasing and Asquith et al. report a similar finding. As a positive signal, we predict that interest-decreasing PPC should be associated with higher announcement returns and that borrowers whose loans include an interest-decreasing PPC should demonstrate a better ex-post performance after loan initiation. We report strong empirical evidence supporting these predictions of the covenant signaling hypothesis. Including an interest-decreasing (as opposed to an interest-increasing) PPC in a loan is associated with an average three-day announcement

\footnotetext{
${ }^{2}$ Our example draws on Asquith et al. (2005), Beatty, Dichev and Weber (2002) and Demiroglu and James (2010).

${ }^{3}$ Their focus is on PPC as a mechanism to alleviate hold-up problems which occur when relationship lenders overcharge borrowers and this leads them to view interest-increasing PPCs as a tighter covenant opposite to the assessment in this paper.
} 
return between 150 and 230 basis points, statistically significant at the $1 \%$ level. Industryadjusted return on assets is significantly larger for interest-decreasing PPC and exceeds the median value by $8 \%$ to $14 \%$ over the first two years of the loan. Similarly, Altman's Z-score is significantly higher for borrowers with interest-decreasing PPC.

This section of our paper is related to Begley (2012) which defines an alternative measure to distinguish among PPC: the degree to which "the loan spread is more sensitive to decreasing borrower performance than to increasing performance". Termed convexity, it is calculated as "the difference between the [initial] level of the spread in the contract and the predicted value of the spread based on the linear interpolation of the pricing grid endpoints." Borrowers with contracts displaying greater convexity have lower spreads and enjoy a lower probability of future financial distress consistent with the interpretation "that strong borrowers use convex contracts to signal otherwise unobservable creditworthiness". At a higher level, greater spread sensitivity to decreasing borrower performance (high convexity) is conceptually similar to interest-increasing PPC while enhanced spread sensitivity to stronger performance (low convexity) is akin to interest-decreasing PPC. To the extent that this comparison between Begley's measures and ours holds, the findings clash. Placed in the context of our characterization of PPC, convexity is defined only for contracts that are both interest-increasing and decreasing. Our tests differ from Begley's by including a more inclusive sample of PPCs.

The rest of the paper is organized as follows. Section 2 discusses the data extraction and matching methodology. Sections 3 and 4 present the univariate and multivariate tests, respectively. Section 5 concludes. 


\section{Data extraction and matching methodology}

We form two samples to examine the impact of PPCs on loan spreads. The first is a pooled sample similar to Asquith et al. (2005). The second is a matched sample, the formation of which we describe below. We extract loan data from Loan Pricing Corporation's DealScan (LPC) database which contains numerous loan deals, each between a syndicate of lenders, or a single lender, and a single borrower. Loan deals are typically composed of several individual loan facilities that can differ based on size, security, maturity, spreads, covenants, and other loan characteristics. The database reports 215,310 loan facilities initiated prior to January 2, 2010. Of these, we eliminate all loan facilities for which the key measure of loan spreads is missing: ALLINDRAWN is defined as the basis point coupon spread over LIBOR plus the annual fee and upfront fee, spread over the life of the loan. Further, we start our sample period in 1994; as Asquith et al. (2005) note, LPC reports comprehensive information on performance pricing beginning in that year. As a result of this filtering, 106,977 loan facilities remain.

Over 20 percent of the observations in the sample (22,776 facilities) have at least one form of PPC. Of these facilities, $96 \%$ contain only one PPC, and the remaining $4 \%$ have two or three. For each of these loan facilities, we identify whether the PPC is accounting based (ACCPPC), or debt-rating based (DEBTPPC) or neither. Table 1 provides descriptive statistics on the types of PPCs in these facilities, their frequency in the sample of facilities with a PPC, along with examples of how these covenants are recorded in loan facility agreements. Whether a PCC is an ACCPPC or a DEBTPPC is clear most of the time by reading its definition. However for a group of PPCs for which the definition is not clear, including those labeled as 'User- 
Condition', we study the terms and conditions of the associated loan agreement and infer whether they are ACCPPC or DEBTPPC or neither. ${ }^{4}$

\section{TABLE 1 HERE}

Table 2 provides descriptive statistics on the type of PCCs at the facility level. Panel A shows the number of facilities with ACCPPCs, DEBTPPCs, and other PPCs. Panel B presents the number and the percentage of facilities that include at least one ACCPPC and no DEBTPPC, at least one DEBTPPC and no ACCPPC, both ACCPPC and DEBTPPC and neither. The largest number of loans with PPCs have an accounting-based PPC and no rating-based PPC (67\%). Around 2\% of loans with PPCs have both ACCPPC and DEBTPPC.

TABLE 2 HERE

For the rest of this study we focus on U.S. dollar denominated loans with available borrower financial information on COMPUSTAT for the fiscal year preceding the loan agreement and with publicly traded stocks listed on CRSP as of the loan activation date ${ }^{5}$. We use Wharton Research Data Services (WRDS) Dealscan-Compustat Link Data to match loan observations with borrowers' financial data (Chava and Roberts, 2008). In addition, we restrict the sample to borrowers with available financial data prior to loan initiation with non-missing total asset values (Item ATQ in Compustat) before and after initiations. We also exclude financial firms (SIC codes 6000-6999) and utilities (SIC codes 4900-4949). After these steps our sample size drops to 26,262 facilities. This includes facilities with and without PPCs. We

\footnotetext{
${ }^{4}$ For example, a type of PPC that is neither an ACCPPC nor a DEBTPPC is designed based on the remaining timeto-maturity of a loan so that the interest rate on the loan increases/decreases with the passage of time.

${ }^{5}$ These criteria are consistent with Demiroglu and James (2010).
} 
designate this sample as the "pooled sample" in which 11,915 loans have PPCs $(45 \%)^{6}$. This percentage is comparable to Adam and Streitz (2013) (42\%) and Manso et al. (2010) (40\%). Control and explanatory variables in uni- and multi-variate analyses encompass both borrower and loan characteristics. Table 3 provides variable definitions.

\section{TABLE 3 HERE}

We next create a matched sample by identifying pairs of facilities that are associated with a single loan deal, where one facility includes a PPC and the other does not. As stated above, forming such pairs allows us to control for lender, borrower, and temporal characteristics, as both elements of the pair are associated with the same lender(s), a single borrower, and a single date. If a single loan deal consists of more than two facilities, then a separate matched pair is identified for every combination of two facilities that differ on the basis of the existence of a PPC. Following this methodology, we identify a matched sample of 1,476 pairs consisting of 1,310 pairs that contain a loan facility element that is identified as ACCPPC, and 166 pairs that contain an element that is identified as DEBTPPC.

While the matched sample controls for all lender, borrower, and temporal characteristics, it does not control for loan characteristics, and differences in such characteristics remain across the two elements of the matched sample. One difference is welcomed - by design each pair consists of one facility with a PPC, and another without. To ensure that differences between the two element groupings are attributable to the status of the PPC alone, other dissimilarities in loan

\footnotetext{
${ }^{6}$ The sample size in Table 2 is 22,776, representing all loans with PPC in the original (raw) data. After the screens explained in this section, the number of loans with PPC drops to 11,915.
} 
characteristics must be addressed through the inclusion of control variables in our multivariate tests. $^{7}$

The next step is to identify whether a PPC is interest-increasing or decreasing by considering the specified adjustments to the initial interest rate spread on loans conditioned on the borrower's subsequent performance changes. If a PPC is associated only with positive (negative) spread adjustments then it is an increasing (a decreasing) PPC. We exclude loans with both positive and negative adjustments.

Descriptive statistics are presented in Table 4 for the pooled and matched samples tabulated by credit metric and interest increasing versus decreasing. The descriptive statistics in Panel A indicate that of the pooled sample of 26,264 observations, 45\% contain a PPC. More specifically, 33\% have an ACCPPC while only 12\% have a DEBTPPC. The matched sample consists of 2,952 observations, or two for each of our 1,476 pairs. By construction, half of these observations have a PPC. Of the borrowers in the pooled sample, 67\% (17,639 out of 26,264) and $69 \%$ of the matched sample loan facilities $(2,042$ out of 2,952) are rated (Rating in Table 4) and our multivariate tests will be performed separately for all borrowers as well as only rated borrowers.

Panels B and C of Table 4 separate PPCs by the direction of adjustment. In Panel B, we see that for accounting-based PPC, the majority of contracts are interest decreasing both for the pooled and matched samples. The sample size declines because of missing information on the specifics of the interest grids. In contrast, for debt-based PPC, Panel C reveals a balanced distribution between interest-increasing and interest-decreasing PPC. More detailed discussion of these results appears later in the paper.

\footnotetext{
${ }^{7}$ The results in this paper are also generally robust to unreported refinements whereby the matched sample is limited to those pairs where both elements share identical loan characteristics, such as security status, syndication, financial covenants, loan options, and loan type.
} 
TABLES 4 and 5 HERE

Table 5 reports the number of loan facility observations that we identify for each year, the proportion of these observations with or without PPCs, and the proportion that are ACCPPC and DEBTPPC. Depending on the year, as few as $27.72 \%$ (1994) and as many as $54.48 \%$ (2005) of our loan facilities have a PPC. Overall, PPC types do not show any specific temporal trend, and the fraction of each type of PPC remains rather stable within our sample period.

\section{Univariate analysis}

\subsection{Impact of any performance pricing covenant}

We begin our measurement of the impact of introducing any PPC with mean of difference tests for the pooled sample of loan facility observations. Next we refine these results for the subsample of matched pairs.

\subsubsection{Pooled sample tests}

For each variable, we calculate the difference of the mean value between those loan facilities without PPCs and those with along with the relevant Student's t-statistics. Since some matched samples contain a small number of observations possibly resulting in a violation of the assumption of normality underlying the parametric Student's $t$ test, we also conduct nonparametric Wilcoxon tests. The results of these tests are reported in Table 6. Our key finding is that loan facilities without PPCs are associated with spreads that are 65.656 basis points higher than loan facilities with PPCs, significant at the $1 \%$ level for both the $t$ and Wilcoxon statistics.

TABLE 6 HERE 
In addition, we find differences between the two groups of loan facilities for all other variables as well significant at the $1 \%$ level for the $\mathrm{t}$ tests (with the exception of Altman's ZScore (significant at 10\%) and Market-to-Book ratio (significant at 5\%)) and at $1 \%$ throughout for the Wilcoxon test. Lower risk borrowers with higher ratings and Z-Scores are more likely to have PPCs consistent with the covenant signaling hypothesis. This result is clouded by the fact that loan facilities without PPCs are more commonly associated with borrowers whose rating is missing making the full risk effect uncertain. We find that loan facilities without PPCs are shorter and smaller than loan facilities with PPCs, and are less often revolvers or syndicated loans. These pooled sample results for controls contrast with Asquith, et al. (2005) who indicate that performance pricing tends to be included in loans with higher re-contracting, adverse selection, and moral hazard costs, such as syndicated loans (SYND), revolving loan facilities (REVOLVER), loans used for takeover purpose, and loans with longer maturities.

Further, loan facilities without PPCs are less often secured but this result is blurred by the tendency for loan facilities without PPCs to be associated with borrowers whose security status is missing; hence the full effect is uncertain.

In brief, while the results in Table 6 constitute strong evidence that loan facilities without PPCs have higher spreads than their counterparts with PPCs, the two samples are widely disparate. To control for differences related to borrower characteristics as well as for unobserved lender differences, we turn to matched pair tests.

\subsubsection{Matched pairs tests}

Difference of means tests using our matched sample control more effectively for nonspread differences between loan facilities without and with PPCs. The results of these tests for all 
PPCs are reported in Table 7. By construction, there is no difference in all borrowers' characteristics between the elements in any pair. Further, within each pair, the lead bank and participant lenders are identical so we also control for any unobserved variation in lender features.

\section{TABLE 7 HERE}

The key result of higher spreads for loan facilities without PPCs reported for the pooled sample holds consistently for the sample of all PPC matches: the mean difference in spread for the matched sample here is 47.7 basis points supporting the results for the pooled sample in Table 6. While our matched sample methodology controls for borrower characteristics, we continue to identify significant differences between the two groups of loan facilities for other variables besides the spread. For the sample of all matches, opposite to our finding for the pooled sample, we find that loan facilities without PPCs bear longer maturities than loan facilities with PPCs, significant at the $1 \%$ level for both the $\mathrm{t}$ and Wilcoxon statistics while there is no significant difference between the size of loans with and without PPCs. Similarly to our finding for the pooled sample, loan facilities without PPCs are less likely to be revolvers or secured, significant at the $1 \%$ level for both the $\mathrm{t}$ and Wilcoxon statistics. For syndication status there is only a weak difference insignificant under the t-test and significant only at the $10 \%$ level for the Wilcoxon test.

To summarize, the difference of means tests for the matched sample demonstrate that loan facilities without PPCs are associated with higher spreads under the refined control setting associated with matched pairs. There continue to be significant loan characteristic differences 
between loan facilities with and without PPCs and in Section 4 we perform multivariate tests to control for these differences.

\subsection{Accounting-based vs. debt-rating based performance pricing covenants}

Table 4 supports Doyle's (2003) characterization of firms with ACCPPC as riskier with higher average spreads, lower credit ratings and higher volatility than borrowers with DEBTPPC. Further, borrowers with ACCPPC are smaller than DEBTPPC borrowers.

Based on the riskier profile of borrowers using ACCPPC, the covenant signaling hypothesis suggests that the inclusion of a PPC will reduce spreads by a greater amount than for borrowers with DEBTPPC. The results in Table 7 support this hypothesis: for ACCPPC matches (Panel C), loan facilities without PPCs are associated with spreads that are 51.9 basis points higher than loan facilities with PPCs, significant at the $1 \%$ level of the $t$ and Wilcoxon statistics. But for DEBTPPC matches (Panel B), loan facilities without PPCs are associated with spreads that are only 14.6 basis points higher than loan facilities without PPCs and lacking in significance. While these results support our hypothesis, it remains for multivariate tests to control for differences within pairs on loan characteristics also documented in Table 7.

\subsection{Interest-increasing vs. interest-decreasing performance pricing covenants}

As stated above, tear sheets describing the pricing grids are required to identify interestincreasing (INTINCR) and interest-decreasing (INTDECR) features in PPCs. These are available for a subset of loan facilities for which summary statistics appear in Table 4, sorted by ACCPPC (panel B) and DEBTPPC (panel C). Interest-decreasing PPC is far more common and the imbalance is due to the far larger ACCPCC subset: there are a total of 1,064 cases of INTINCR and 3,981 observations of INTDECR in the pooled sample and 63 INTINCR and 818 INTDECR 
for the matched pairs. In contrast, for DEBTPPC, the two types are fairly evenly matched with 321 INTINCR and 254 INDECR in the pooled sample and 31 INTINCR and 21 INTDECR in the paired sample. This imbalance is similar to that reported in Asquith et al. (2005).

We show earlier that ACCPPC borrowers are riskier. Taken with their preponderant use of INTDECR over INTINCR PPC, this suggests that INCTDECR borrowers are riskier. Table 4 verifies this idea: In Panels B and C, we see that borrowers with INTDECR have higher spreads, lower credit ratings, and are more likely to use security - all consistent with higher risk.

Demiroglu and James provide evidence for the impact of including a tight covenant in a loan contract on borrower announcement return and ex-post performance. However, they are silent on its impact on loan spreads. As a tight covenant, we predict that inclusion of an INDECR PPC is expected to reduce spreads according to the covenant signaling hypothesis. As noted above, this effect is in the opposite direction to the credit adjustment option which results in higher spreads in the presence of INDECR PPC feature. Therefore, we can predict that INTDECR PPCs lower spreads less than INTINCR PPCs and may possibly increase them. The matched pairs tests in Table 7 show that INTDECR PPC is associated with a spread reduction of 41.237 basis points (Panel E) while for INTINCR PPC the spread is lower by 70.165 basis points (Panel D). Hence, the relative results show that the spread-increasing credit adjustment option is offset by the spread-reducing signaling effect.

It is also important to note that the fraction of accounting-based and rating-based PPCs differs in each sample. The samples in Table 4, Panel B and C include both ACCPPC and DEBTPPC. The 94 INTCR pairs include 63 ACCPPC and 31 DEBTPPC. For INTDECR, the numbers are 818 and 21, respectively. The predominance of ACCPPC suggests that a part of the 
spread-decreasing role of INTDECR PPC derives from the features of borrowers selecting ACCPPC as discussed above. This is consistent with our previous finding.

Overall, this section of our matched pairs tests reinforces the results in Asquith et al. (2005) assigning a spread-reducing role to INTINCR PPC. This type of PPC provides a valuable option to lenders for which borrowers are compensated. By separating ACCPPC and DEBTPPC in our tests, we show that the higher risk profile of borrowers using ACCPPC reinforces the covenant signaling effect. While this separation of different PPC types in pricing tests constitutes a unique contribution of the present paper, our results for interest-increasing PPC are consistent with those of Asquith et al.

To control for selection bias that could arise due to different risk levels, Asquith et al. employ probit regressions predicting the propensity to use INTINCR and INTDECR PPC. In this paper, we control for risk differences through matched pairing. Our approach improves on Asquith et al. by allowing for perfect controls of borrower risk as well as of unobserved lender risk. This suggests that the positive coefficient on INTDECR (increasing spread) in their study may be due to unobservable risk imperfectly controlled. An alternative explanation is that our finding that INTDECR PPC is associated with lower spreads is biased due to imperfect controls for differences in loan features such as maturity and security. To distinguish between these explanations requires multivariate testing and we return to this point below.

\subsection{Nonparametric univariate counting tests}

The univariate test results discussed so far demonstrate that through using the matched pair methodology, we are able to create two groups that are highly similar. The parametric difference of means tests above provide strong evidence that loan facilities without PPCs have spreads that are approximately 51.896 basis points higher than matched loan facilities with 
ACCPPCs, while the difference between matched loan facilities without and with DEBTPPCs is only 14.617 basis points. For further checking, we next count the number of times that the loan facility without PPCs in a matched pair is associated with higher, identical, or lower spreads, than the paired loan facility with the PPC. We report the results of these counting tests in panels A (all matched pairs), B (ACCPPC), C (DEBTPPC), D (INTINCR) and E (INTDECR) of Table 8 separately for matched pairs associated with borrower Standard \& Poor's credit ratings of A, B, C, D, and unrated. We also tabulate the percentage lower, higher, and identical, and the number of pairs for each sample.

\section{TABLE 8 HERE}

For the all PPC and ACCPPC matched pair samples in Table 8, we find further strong evidence that loan facilities without PPCs are associated with higher spreads than those with PPCs. Overall, for $62 \%$ of all matched pairs and $66 \%$ of ACCPPC matched pairs, the loan facility without the PPC is associated with higher spreads than the loan facility with the PPC, while the reverse is true for only $15 \%$ and $14 \%$ of the matched pairs, respectively. We find similar results for the $\mathrm{A}, \mathrm{B}, \mathrm{C}, \mathrm{D}$, and unrated borrower cases significant in most cases at the 0.05 or 0.01 level.

The results for the DEBTPPC matched pair sample are less strong, and correspond to our findings for the parametric difference of means tests. Overall, 26\% of matched pairs exhibit higher spreads for the loan facility without the PPC over the loan facility with the PPC, while the reverse is true in $17 \%$ of the matched pairs. More interestingly, spreads are identical in $57 \%$ of the matched pairs. These results are generally consistent for borrowers rated A, B, and D. All 5 
observations in this sample where the borrower is rated $\mathrm{C}$ have a higher spread if they do not have a PPC.

In summary, the nonparametric counting tests in Table 8 confirm that loan spreads are typically higher for loans without PPC within matched pairs (Panel A). This finding is driven by the ACCPPC subsample (Panel B); the spreads are typically identical for DEBTPPC matched pairs (Panel C). The results are also consistent when one separates observations based on the directions of PPCs (increasing or decreasing) reinforcing the greater impact on spreads of interest-decreasing PPC (Panels D and E).

\section{Multivariate tests}

Table 9 presents the correlations between the variables used in the regression tests. ${ }^{8}$

\section{TABLE 9 HERE}

To test the core spread-PPC relation, all of the regression tests use spreads or change in spreads as the dependent variable with indicator variables for the presence of selected types of PPCs as independent variables. For each sample, we estimate four types of regression models based on the choice of control variables measuring borrower risk: no borrower risk controls; accounting and financial ratios, such as leverage, ROA, volatility, market to book and size; Altman's Z Score; and credit rating. All models are controlled for covenant and time (year) fixed effects. We perform the regressions separately for the pooled, ACCPPC, and DEBTPPC matched pair samples as well as for the matched interest-increasing and decreasing samples.

\section{TABLE 10 HERE}

\footnotetext{
${ }^{8}$ In the regressions in Table 10, we conduct variance inflation factor (VIF) tests where VIF $=1 /\left(1-\mathrm{R}^{2}\right)$ (Belsley, Kuh and Welsch, 1980). The maximum VIF observed is 7.68. Since, none of the test statistics exceed the critical value of 10 , we conclude that multicollinearity is not severe.
} 


\subsection{Regression tests, pooled sample}

The results for the pooled sample are reported in Panel A of Table 10 where the main explanatory variables are ACCPPC and DEBTPPC. The results are robust to the choice of borrower risk controls. There is strong evidence that ACCPPC covenants reduce spreads. The coefficient associated with ACCPPC varies between -50.21 and -58.84 basis points across the four models in Panel A statistically significant at the 99\% confidence level, while the coefficients associated with DEBTPPC are all insignificant at any conventional confidence level. The sample size drops for Model (4) as it includes only sample firms with observed credit ratings.

\subsection{Regression tests, ACCPPC and DEBTPPC matched samples}

The above results suggest that loans with ACCPPC are associated with lower spreads than are loan facilities without PPCs. Yet as we demonstrated in Section 3, there are many important differences between the with- and without-PPC samples; hence even in a multivariate setting these results may be attributable to differences unrelated to the presence or absence of PPCs. If, however, as hypothesized, these results flow from the presence of PPCs, then they should continue to hold in the more refined control setting that we created using our matching methodology.

The results for the ACCPPC matched sample are presented in Panel B of Table 10 and provide strong evidence that ACCPPC results in lower spreads, ranging from -59.50 to -84.72 basis points across four models and significant at the $99 \%$ level.

The findings for the DEBTPPC matched sample are presented in Panel C and suggest that this form of PPC is associated with lower spreads only for rated borrowers (Model 4). Because 
the sample size is reduced for this model, caution is required when comparing the magnitude of coefficients across samples.

\subsection{Regression tests, INTINCR and INTDECR matched samples}

We also conduct similar regressions for the matched samples of INTINCR and INTDECR PPC.) The results are strongly significant for ACCPCC coefficients, specifically for the INTINCR sample (Panel D) where the coefficient for ACCPCC ranges between -94.02 to 154.65 at the $10 \%$ and $1 \%$ percent levels, respectively. The same coefficients for the INTDECR group (Panel E) are lower between -6.64 to -42.1 and fail to obtain significance in two models. The quality of results for DEBTPCC is weaker, not significant for the INTINCR matched sample and weakly significant at the $10 \%$ level of just one model for the INTDECR matched sample. The results in this part are consistent with Asquith et al. They support the notion that interestincreasing PPCs provide an option for lenders and since this option is valuable, borrowers are compensated by paying a lower rate on their loan at the time of loan initiation. The results also resolve some of the ambiguity around the findings in our univariate analysis, showing that the negative effect of inclusion of an INTDECR PPC on spreads is mainly due to the fact that most of these PPCs are also accounting-based. To examine the signaling impact of INTDECR PPCs we follow the approach in Demiroglu and James (2010) in sub-sections 4.6 and 4.7 below.

\subsection{Control variables}

As expected, in Table 10 we find that spreads are lower for higher rated, less leveraged, less volatile, and larger borrowers, all significant at the $1 \%$ level for both the pooled (Panel A) and the matched ACCPCC (Panel B) samples and generally significant for the matched DEBTPCC sample (Panel C). We also find a significant positive relation between spreads and facility maturity for pooled and DEBTPCC samples but not for the ACCPCC set. In all samples, we find 
strong evidence of lower spreads for revolvers while the presence of security is associated with higher spreads reflecting the earlier literature. We also observe higher spreads for facilities for which security status is missing. Finally, spreads are negatively related to the profitability of the borrower, measured by ROA, suggesting that poorly performing firms incur higher costs of debt.

\subsection{Robustness test, marginal impact analysis}

Endogeneity is an important issue when examining whether loan contract features are priced. The matching methodology employed extensively to this point is designed to overcome a potential omitted variables bias by examining variations within loan packages. Here, we adopt an alternative methodology to address endogenity by estimating regressions in which the unit of observation is a loan package, where the dependent variable is the difference between the spreads of loans with and without a PPC, and explanatory variables are differences in PPC and covenant dummies and loan characteristics. ${ }^{9}$

\section{TABLE 11 HERE}

The results in Table 11 show that within a loan package, a loan with an ACCPPC on average has a spread that is just under 40 basis points lower than a loan without one (Models (1) and (2)). Also an INTINCR covenant is accompanied by a negative effect on spreads whereas an INTDECR PPC is associated with a positive effect consistent with our hypotheses. These results are in line with the notion that borrowers are compensated with lower spreads when committing to have an INTINCR PPC on their loans as these covenants provide an option to the lender to increase rates when the borrower is performing poorly. INTDECR PPC on the other hand works predominantly as an option for the borrower. It enables borrowers to reduce interest rates if they can enhance the covenant variable.

\footnotetext{
${ }^{9}$ We thank the referee for suggesting this methodology.
} 
Table 11 also shows that larger loans and revolvers are associated with lower spreads when they compared to other loans in the same package. These results are consistent and significant at $1 \%$ confidence level.

\subsection{The effect of INTDECR PPC inclusion on announcement returns}

Under the covenant signaling hypothesis, interest-decreasing PPCs (tight covenants) constitute a signal of higher future credit quality, consistent with the notion that only borrowers expecting improvements in their credit conditions agree to accept the cost of including these clauses in their contracts. This suggests that interest-decreasing PPCs should be associated with (1) higher loan announcement returns, and (2) better ex post operating performance as measured by improvements in profitability and Z-score ${ }^{10}$. In this sub-section we examine the effect of inclusion of an INTDECR PPC on announcement returns and in the next sub-section we measure the effect on ex post performance.

\section{TABLE 12 HERE}

Table 12 explores the relationship between the stock price reaction to loan announcements and the inclusion of an INTDECR PPC (tight covenant), as opposed to an INTINCR PPC (relaxed covenant). If announcement of loans with tight covenants conveys favorable private information regarding the borrower, then we expect to observe higher stock returns for such loans.

At this point we cannot employ our matching technique as loans within the same package have identical announcement dates. Since we are examining stock returns, the unit of observation

\footnotetext{
${ }^{10} \mathrm{We}$ also predict that INTDECR PPCs are associated with higher future credit ratings. However, the change in ex post borrower ratings in our sample does not have sufficient variation to provide statistically significant results.
} 
is the borrower. We limit this analysis to issuers of loans with a Total Debt to Cash Flow PPC or a Senior Debt Rating PPC which are the most popular accounting and rating based PPCs, respectively. To facilitate comparison between INTINCR and INTDECR PPCs and their signaling effects, we restrict the sample to loan packages that have at least one PPC. In this way we control for the effect of PPC inclusion and focus the analysis on the impact of PPC direction. We also exclude loan packages with multiple loans that have covenants with different directions. After imposing these filters our sample consists of 1,822 borrowers. To identify loan announcements, we search Factiva archives for a news report for 30 day before and after the loan inception date. As the announcement date we use the earlier of the date of the press report or the loan inception date. We were able to identify announcement dates for 943 of the loans in our sample constituting roughly half of observations ${ }^{11}$. Following Demiroglu and James (2010), we compute cumulative market-adjusted abnormal returns over a three-trading-day window centered on the announcement date.

Our results show that the presence of an INTDECR covenant is strongly associated with a positive stock market reaction. Table 12 provides the regression analysis with different combinations of firm specific and loan specific characteristics. The results are robust and independent of the choice of control variables; inclusion of an INTDECR PPC is associated with an average three-day announcement return between 150 to 230 basis points, statistically significant at the $1 \%$ level. Further, larger firms and those with higher Altman's-Z Scores elicit a lower announcement return consistent with the notion that there is less value in signaling for these firms.

\footnotetext{
${ }^{11}$ Maskara and Mullineaux (2011) state that loan announcements are rare and driven by factors such as information asymmetry and perceived materiality. Notwithstanding the selection issue in loan announcements, since we are comparing the returns among borrowers with announcement returns, this issue does not affect our findings.
} 


\subsection{The effect of INTDECR PPC inclusion on ex post performance of the borrower}

In this sub-section we examine the relationship between inclusion of an INTDECR PPC and ex post changes in operating performance. We hypothesize that borrowers which accept INTDECR PPCs are the ones that expect their performance to improve. Given our expectation that PPCs are more likely to be included in short-term loans in a package because borrowers cannot predict their performance far into the future, we examine how a PPC is related to shortterm and long-term ex post performance. Following Demiroglu and James (2010), we measure performance by Return on Assets (ROA) and Altman's-Z Score in Table 13 where each model includes different control variables.

\section{TABLE 13 HERE}

We examine the relationship between the inclusion of an INTDECR covenant at the initiation of the loan and subsequent industry-adjusted changes in ROA and Altman's Z-Score. As in Demiroglu and James (2010), we compute industry-adjusted changes as the difference between the change for each borrower and that for the median firm within the same four-digit SIC Code. For presentation purposes we report only the coefficient estimates and standard errors corresponding to decreasing covenant dummies. The results in Table 13 demonstrate that these covenants are associated with higher values of both ROA and higher Altman's Z -Score, as measures of performance and credit quality over one and two years after loan initiations. The results are stronger for ROA. On average, ROA of borrowers whose loans include an INTDECR PPC grows by 0.004 to 0.007 more than the ROA of borrowers with INTINCR PPC loans over the first two years after loan initiation. Table 4 provides perspective on these numbers showing that the ROA of an average borrower is 0.05 . Hence, the results in Table 13 reveal that, on 
average, INTDECR borrowers perform better than INTINCR borrowers by $8 \%$ to $14 \%$ over the first two years after loan initiation. Similar results hold when we use Z-Score as an overall measure of borrower quality. On average the Z-Score improves by 0.167 to 0.557 when an INTDECR PPC is utilized rather than INTINCR PPC. Considering the average Z-Score of 4.76 (Table 4), this translates into a relative improvement of $3.5 \%$ to $11.7 \%$ in overall quality (or distance from default).

In the context of Demiroglu and James (2010), we show that, consistent with our prior argument that interest decreasing PPCs are tight covenants, firms that select such covenants experience an increase in relative performance after loan initiation as predicted by the covenant signaling hypothesis. The results remain robust after controlling for borrower risk and loan characteristics.

\section{Conclusions}

Performance pricing covenants (PPC) are predicted to reduce loan spreads as they serve to control costs associated with asymmetric information, adverse selection, moral hazard and recontracting. This paper tests and supports this view using a carefully matched sample of loan facilities initiated between January 1, 1994 and January 1, 2010 and documented in the Loan Pricing Corporation DealScan database.

An important new result is that the type of performance pricing matters: compared against controls, loans with accounting-based performance pricing enjoy significantly lower spreads while we detect only small and weakly significant differences in loans which base performance pricing on debt ratings. After controlling for borrower and lender characteristics, accounting-based PPC results in spreads that are approximately 52 basis points lower than they would be without the PPC in univariate tests, and 50-59 basis points lower in subsequent 
multivariate tests. In contrast, debt-rating-based PPC results in spread differentials that are not statistically different from zero. These results reflect the role of PPC in resolving information asymmetry which is more prevalent in riskier borrowers more likely to employ accounting-based covenants. Further, they are also consistent with Doyle (2003) who suggests that accounting ratios are more timely reflectors of changes in credit quality. While accounting ratios are updated quarterly, debt ratings are revised at most every six months except when a firm experiences a crisis. Accordingly, accounting ratios are more sensitive and better reflect changes in borrowers' credit risk and therefore, accounting-based performance pricing adds more value than debt-rating based.

In addition, our paper elucidates interest-decreasing PPC in the covenant signaling framework of Demiroglu and James (2010) in which firms take on tight covenants as a signal that their financial condition will improve. This leads to the prediction, strongly supported in our tests, that interest-decreasing PPC should be associated with better ex post performance and higher announcement returns.

Finally, our matching methodology uncovers an interesting empirical regularity. Firms often take out several loan facilities from the same lenders on the same day and typically include a performance pricing feature in the shorter-maturity loan only. This finding contrasts with Asquith et al. (2005) who report that the probability of employing performance-pricing increases with maturity. According to our results, performance pricing tends most often to be a feature of loans with shorter maturities. This is consistent with the notion that borrowers have limited ability to predict their performance far into the future. Thus, for longer-maturity loans, borrowers might be unwilling to reduce their initial borrowing costs by including performance pricing fearing that, if their performance deteriorated in the future, loan spreads would increase resulting 
in higher ex post borrowing costs. For loans with shorter maturities, borrowers are likely able to predict their companies' performance with more confidence and if they think that their companies' performance will get better, or at least not get worse, they will be willing to include performance pricing in their loan contracts and obtain lower loan spreads. Put another way, firms balance the signaling benefits of performance pricing against the danger of facing higher costs in future if the signal is false. Since uncertainty in forecasts increases with the time horizon, there is a point beyond which performance pricing is seen as too risky. Testing this conjecture is left for future research. 


\section{References}

Adam, T. and D. Streitz. 2013. Bank Lending Relationships and the Use of PerformanceSensitive Debt, Working Paper, Financial Management Association European Conference, Luxembourg.

Asquith, P., A. Beatty, J. Weber. 2005. Performance Pricing in Bank Debt Contracts. Journal of Accounting and Economics 40 (Issues 1-3, December), 101-128.

Begley, B. 2012. Signaling, Financial Constraints, and Performance Sensitive Debt. University of Michigan Working Paper, Available at SSRN: http://ssrn.com/abstract=2140217 or http://dx.doi.org/10.2139/ssrn.2140217

Bhanot, K. and A.S. Melo. 2006. Should Corporate Debt Include a Rating Trigger? Journal of Financial Economics 79, 69-98.

Belsley, D.A., Kuh, E., and R.E. Welsch. 1980. Regression Diagnostics: Identifying Influential Data and Sources of Collinearity, John Wiley \& Sons, New York.

Beatty, A., I.D. Dichev, J. Weber. 2002. The Role and Characteristics of Accounting-Based Performance pricing in Private Debt Contracts. Working Paper. Penn State University, University of Michigan, and MIT. June.

Bharath, S T. 2002. Agency costs, bank specialness and renegotiation, Working Paper, New York University.

Demiroglu, C. and C. M. James. 2010. The Information Content of Bank Loan Covenants. Review of Financial Studies 23 (10), 3700-3737.

Doyle, J.T. 2003. Credit Risk Measurement and Pricing in Performance pricing-Based Debt Contracts. Working Paper. University of Michigan.

Gerleanu, Nicolas, and Jeffrey Zwiebel. 2005. Design and Renegotiation of Debt Covenants, University of Pennsylvania Working Paper.

Gottesman. A.A., and G.S. Roberts. 2004. Maturity and Corporate Loan Pricing. Financial Review (February).

---, 2007. Loan Rates and Collateral. Financial Review 42, 401-427.

Helwege, J. and C. M. Turner. 1999. The slope of the credit yield curve for speculative-grade issuers, Journal of Finance 54 (October), 1869-1884.

Koziol, C. and J. Lawrenz. 2010. Optimal Design of Rating-Trigger Step-Up Bonds: Agency Conflict versus Asymmetric Information, Journal of Corporate Finance 16, 182-204. 
Manso, G., B. Strulovici and A. Tchistyi. 2010. Performance-Sensitive Debt, Review of Financial Studies23 (5), 1819-1842.

Maskara, P. and D.J. Mullineaux. 2011. Information Asymmetry and Self-Selection Bias in Loan Announcement Studies, Journal of Financial Economics 101, 684-694.

Panyagometh, K., and G.S. Roberts. 2010. Do Lead Banks Exploit Syndicate Participants? Evidence from Ex Post Risk. Financial Management (Spring), 273-299. 
Table 1: PPC Types. The table provides descriptive statistics on the types of PPCs in the universe of DealScan bank loans from January 1, 1994 to January 1,2010 issued by nonfinancial, non-utility US firms. The frequencies of loans with each PPC along with examples of how these covenants are mentioned in loan facility agreements are also provided. Each PPC is then categorized as an ACCPPC (accounting based PPC) or a DEBTPPC (debt rating PPC) based on its title. If there is ambiguity about the type of a PPC, then we investigate the issue further by reading the details of terms and conditions of the loan agreement as provided by Deal Scan.

\section{PPC Type}

Index

Net Income

\section{EBITDA}

Borrowing Base

Moodys Rating

Availability

Commercial Paper

Rating

Senior Leverage

Debt Service Coverage

Outstandings

\section{Frequency}

Margin, over secondary CP rate, is based on the matrix which is linked to the Taiwan Cooperative Credit Risk Index (TCRI): 90bp for TCRI=3, 100bp for TCRI=4, 110bp for TCRI=5, 126bp for TCRI $>=6$

The margin on the revolver is tied to net profit margin matrix: for NT\$ - 150bp over secondary CP rate for net profit margin $<0 ; 125 \mathrm{bp}$ over secondary CP rate for net profit margin $0-4.9 \%$; $90 \mathrm{bp}$ over secondary CP rate for net profit margin 5\% or above. For US\$ - 150bp over TAIFX3 if net profit margin $<0$; $125 \mathrm{bp}$ over TAIFX3 if net profit margin $0-4.9 \%$; $90 \mathrm{bp}$ over TAIFX3 if net profit margin $5 \%$ or above

Pricing is as indicated initially, tied to company's adjusted EBITDA (in millions) thereafter.

Pricing as indicated initially, tied to company's borrowing base utilization (in percentage) thereafter. Company pays a SBLC fee = applicable LIBOR margin and an issuance fee of $12.5 \mathrm{bps}$.

Pricing is as indicated thru 9/30/05, tied to co.'s sr. unsec'd LTD ratings by Moody's thereafter. Indicated level 1 applies for ratings >= B1 and level 2 when $<$ B1.

Pricing is as indicated thru 06/30/09, tied to co.'s average excess availability (in $\$$ millions) thereafter. Level 1 applies when average excess availability is $<=\$ 5 \mathrm{M}$, Level 2 when availability is $>\$ 5 \mathrm{M}$ but $<$ $\$ 10 \mathrm{M}$, Level 3 when availability is $>=\$ 10 \mathrm{M}$.

Pricing is as indicated initially. If co. is split rated A-1/P-2 or A-2/P-1, LIB +25 , ann fee $=15$ bps pricing applies.

Ratio $=$ sr. debt to capital. P+0, LIB +62.5 and commit. fee $=20$ bps when co.'s sr. long-term debt rating $>$ or $=\mathrm{BBB}-/ \mathrm{Baa} 3$ and the sr. leverage ratio $<$ or $=0.45$.

Pricing is as indicated initially, tied to company's debt service coverage ratio thereafter. Level 1 applies with ratios $>1.25: 1$ but $<=1.35: 1$; level 2 applies with ratios $>1.35: 1$ but $<=1.75: 1$ and level 3 applies with ratios $>1.75: 1$.

Pricing is as indicated thru $12 / 2 / 95$; tied to borrow. base outstands. thereafter. Pricing increases by 100 bps beg. 9/6/95 if pfd. stk. has not been redeemed in full.

\section{ACCPPC/DEBTPPC}

Neither

ACCPPC

ACCPPC

ACCPPC

DEBTPCC

ACCPPC

DEBTPCC

ACCPPC

ACCPPC

Requires Further Investigation 
Debt to Tang. Net

Worth

Fixed Charge

Coverage

Interest Coverage

Senior Debt to Cash

Flow

Maturity

Leverage

User Condition
Pricing is as initially indicated, tied to co.'s debt to tang. net worth and fixed charge coverage ratios thereafter.

Pricing is as indicated initially, and is tied to co.'s fixed charge coverage and consol. debt less consol. cash holdings to consol. net worth ratios. Trade LC fee is as follows: Level $1=90 \mathrm{bps}$, Level $2=$ 52.5 bps, Level $3=27.5$ bps.

579 Pricing is tied to co.'s consol. EBITDA to consol. interest expense ratio.

807 Pricing is as indicated initially, tied to co.'s secured debt to consol. EBITDA ratio thereafter.

Pricing is as indicated initially and tied to deal's maturity (years) thereafter. Level 1 will apply in years 1 and 2 , level 2 in years 3 and 4, and level 3 in year 5.

Pricing is as indicated thru 12/31/93, tied to co.'s leverage and interest coverage ratios thereafter.

Example 1: Usr Cndtn 1 = co.'s net worth (\$mils.); Usr Cndtn 2 = co.'s EBITDA (\$mils.).

Example 2: Pricing is as indicated thru 6/5/98, tied to co.'s conforming assets plus unfunded partners capital to funded debt ratio and unfunded partners capital (amounts in $\$$ millions). If unfunded partners capital is $<$ senior debt and is $<\$ 500 \mathrm{M}$, Pricing will be as follows when unfunded partners capital is $>\$ 250 \mathrm{M}$ but $\langle=\$ 500 \mathrm{M}:>=2.5: 1, \mathrm{P}+0, \mathrm{LIB}+75$, commitment fee $=20 \mathrm{bps},>=2.25: 1$, but $<2.5: 1, \mathrm{P}+0, \mathrm{LIB}+87.5$, commitment fee $=20 \mathrm{bps}$ (commitment fee increase to $25 \mathrm{bps}$ when senior unsecured LTD rating is $<\mathrm{BBB}$ - and Baaa3), $>=2: 1$, but $<=2.25: 1, \mathrm{P}+0, \mathrm{LIB}+100$, commitment fee $=$ 25 bps, $>=1.85: 1$, but $<2: 1, \mathrm{P}+0, \mathrm{LIB}+112.5$, commitment fee $=25 \mathrm{bps},>=1.7: 1$, but $<1.85: 1, \mathrm{P}+0$, LIB +125 , commitment fee $=30$ bps but $<1.7: 1, \mathrm{P}+0, \mathrm{LIB}+137.5$ commitment fee $=30 \mathrm{bps}$; Pricing will be as follows when unfunded partners capital is $\langle=\$ 250 \mathrm{M}:>=3: 1, \mathrm{P}+0, \mathrm{LIB}+75$, commitment fee $=20$ bps $>=2.75: 1$, but $<3: 1, P+0, \mathrm{LIB}+87.5$, commitment fee $=20$ bps (commitment fee increase to 25 bps when senior unsecured LTD rating is $\langle$ BBB- and Baaa3) $>=2.5: 1$, but $<2.75: 1$, $\mathrm{P}+0, \mathrm{LIB}+100$, commitment fee $=25 \mathrm{bps},>=2.25: 1$, but $<2.5: 1, \mathrm{P}+0, \mathrm{LIB}+112.5$, commitment fee $=$ 25 bps, $>=2: 1$, but $<=2.25: 1, \mathrm{P}+0, \mathrm{LIB}+125$, commitment fee $=30 \mathrm{bps},>=1.85: 1$, but $<2: 1, \mathrm{P}+0$, $\mathrm{LIB}+137.5$, commitment fee $=30$ bps, but $<1.85: 1, \mathrm{P}+=12.5, \mathrm{LIB}+162.5$, commitment fee $=35$ bps. Indicated LIBOR margin increase by 12.5 bps when co., California Public Employees' Retirement Systems or any unfunded partners capital ratio is senior unsec'd LTD rating > BBB- and Baa3 by S\&P or Moody's. Commitment fee of Levels 4 and 7 increase to 25 bps when rating is> BBB-and Baa3.

Example 3: Pricing is as indicated initially, tied to company's average outstandings (in millions) thereafter. Company pays a SBLC fee $=$ applicable LIBOR margin and an issuance fee of $12.5 \mathrm{bps}$. Company pays a commercial LC fee $=50 \%$ of applicable LIBOR margin.
ACCPPC

ACCPPC

ACCPPC

ACCPPC

Neither

ACCPPC

Potentially Both (Requires Further Investigation) 
Subordinated/ Senior Debt Rating

Total Debt to Cash Flow
Pricing is as indicated initially, tied to company's senior unsecured long-term debt ratings by S\&P and Moody's thereafter (undisclosed). If split-rated, the higher rating applies. If split-rated by more then one level, the rating immediately above lower level applies. Company pays a SBLC fee $=$ applicable LIBOR margin and an undisclosed issuance fee.

10,805 Pricing is as indicated initially, tied to co.'s consolidated debt to EBITDA ratio thereafter.
DEBTPCC

ACCPPC 
Table 2: Descriptive statistics on accounting-based and rating-based PPCs. In Panel A the number of facilities with ACCPPCs, DEBTPPCs, and other PPCs are provided. Panel B presents the number and the percentage of facilities that include at least one ACCPPC and no DEBTPPC, at least one DEBTPPC and no ACCPPC, both ACCPPC and DEBTPPC and neither. The sample includes all bank loans in the DealScan dataset from January 1, 1994 to January 1, 2010 issued by non-financial non-utility US firms.

\section{Panel A: Number of ACCPPC, DEBTPPC and other PPCs in loan facilities}

$\begin{array}{cccc}\begin{array}{c}\text { Number of ACCPPC } \\ \text { terms in the facility }\end{array} & \begin{array}{c}\text { Number of DEBTPPC } \\ \text { terms in the facility }\end{array} & \begin{array}{c}\text { Number of non- } \\ \text { ACCPPCC/DEBTPPC } \\ \text { terms in the facility }\end{array} & \text { Number of Facilities } \\ 0 & 0 & 1 & 1,525 \\ 0 & 0 & 2 & 2 \\ 0 & 1 & 0 & 5,475 \\ 0 & 1 & 1 & 40 \\ 0 & 2 & 0 & 26 \\ 1 & 2 & 1 & 1 \\ 1 & 0 & 0 & 14,803 \\ 1 & 0 & 1 & 26 \\ 1 & 1 & 0 & 379 \\ 1 & 1 & 1 & 1 \\ 2 & 2 & 0 & 6 \\ 2 & 0 & 0 & 458 \\ 2 & 0 & 1 & 3 \\ 3 & 0 & 0 & 6\end{array}$

Total: 22,776

Panel B: Number of Loan Facilities with Different PPC Type Combinations

Inclusion of ACCPPC/DEBTPPC

$\mathrm{ACCPPC}$ and not DEBTPPC

DEBTPPC and not ACCPPC

Both ACCPPC and DEBTPPC

Neither ACCPPC nor DEBTPPC
Number of Facilities

15,311

5,542

396

1,527

Total: 22,776
Percentage of Facilities

$$
\begin{gathered}
67 \% \\
24 \% \\
2 \% \\
7 \%
\end{gathered}
$$

Total: $100 \%$ 
Table 3: Loan and Borrower Characteristics. The definitions of the dependent and explanatory variables used in univariate and multi-variate analyses are provided in this table.

\section{Panel 1: Main Borrower Characteristics:}

Leverage

MB

Rated

Rating

ROA

Ticker

Volatility

Z-Score

\section{Total Debt/Total Assets}

Market value of equity divided by book value of equity

An indicator that equals unity if the borrower is rated

S\&P Current Credit Rating quantified from 1 to 8.This variable is an appraisal of past performance of a stock's earnings and dividends and the stock's relative standing as of a company's current fiscal year-end. Growth and stability of earnings and dividends are key elements in establishing Standard \& Poor's quality rankings. The rating ranges from A+ (quantified as 8 in our calculations) to Liquidation status (assigned a value of 1 in our calculations).

Earnings before interest and tax to total assets

An indicator variable that equals unity if the borrower has a credit rating and zero otherwise

The volatility used in the fair value calculation for stock options

Altman's Z-score, is a measure of bankruptcy likelihood and is based on five financial ratios that can be calculated from data found on Compustat and CRSO. Altman's Z-score is calculated as follows:

$\mathrm{Z}$-Score $=1.2 \mathrm{~A}+1.4 \mathrm{~B}+3.3 \mathrm{C}+0.6 \mathrm{D}+1.0 \mathrm{E}$

Where:

$\mathrm{A}=$ Working Capital/Total Assets

$\mathrm{B}=$ Retained Earnings/Total Assets

$\mathrm{C}=$ Earnings Before Interest \& Tax/Total Assets

$\mathrm{D}=$ Market Value of Equity/Total Liabilities

$\mathrm{E}=$ Sales/Total Assets

Panel 2: Main Loan Characteristics:

ALLINDRAWN

Facility Amount

PPC

REVOLVER

SYND

SECURED

SECUREDMISS

Loan Maturity (Month)
The basis point coupon spread over LIBOR plus the annual fee and upfront fee, stated at the time of loan initiation.

The facility size

An indicator that equals unity if the loan has a PPC

An indicator that equals unity if the loan is a revolving loan and zero otherwise.

An indicator that equals unity if the loan is syndicated and zero otherwise.

An indicator that equals unity if the loan is designated as secured by the database and zero otherwise.

An indicator that equals unity if the securitization status is missing.

Months to Maturity 
Table 4: Descriptive statistics for each variable. The number of observations, mean value and standard deviation for each variable are reported for both the full and matched paired samples, for the following samples: For all observations, ACCPPC, and DEBTPPC (Panel A); for observations that are both ACCPPC and INTINCR and observations that are both ACCPPC and INTDECR (Panel B); and for observations that are both DEBTPPC and INTINCR and observations that are both DEBTPPC and INTDECR (Panel C). Variable definitions are presented in Table 3.

\begin{tabular}{|c|c|c|c|c|c|c|c|c|c|c|c|c|c|c|c|c|c|c|}
\hline & \multicolumn{9}{|c|}{ Pooled Sample } & \multicolumn{9}{|c|}{ Matched Sample } \\
\hline & \multicolumn{3}{|c|}{ All } & \multicolumn{3}{|c|}{ ACCPPC } & \multicolumn{3}{|c|}{ DEBTPPC } & \multicolumn{3}{|c|}{ All } & \multicolumn{3}{|c|}{ ACСРPC } & \multicolumn{3}{|c|}{ DEBTPPC } \\
\hline & Number & Mean & Std. & Number & Mean & Std. & Number & Mean & Std. & Number & Mean & Std. & Number & Mean & Std. & Number & Mean & Std. \\
\hline ALLINDRAWN & 26,264 & 204.64 & 148.56 & 8,721 & 194.07 & 96.51 & 3,084 & 86.01 & 76.20 & 2,952 & 256.89 & 124.47 & 1,310 & 250.42 & 84.98 & 166 & 95.91 & 84.98 \\
\hline PPC & 26,264 & 0.45 & 0.50 & 8,721 & 1.00 & 0.00 & 3,084 & 1.00 & 0.00 & 2,952 & 0.50 & 0.50 & 1,310 & 1.00 & 0.00 & 166 & 1.00 & 0.00 \\
\hline ACСРPC & 26,264 & 0.33 & 0.47 & 8,721 & 1.00 & 0.00 & 3,084 & 0.07 & 0.25 & 2,952 & 0.44 & 0.50 & 1,310 & 1.00 & 0.00 & 166 & 0.00 & 0.00 \\
\hline DEBTPPC & 26,264 & 0.12 & 0.32 & 8,721 & 0.02 & 0.15 & 3,084 & 1.00 & 0.00 & 2,952 & 0.06 & 0.23 & 1,310 & 0.00 & 0.00 & 166 & 1.00 & 0.00 \\
\hline INTINCR & 26,264 & 0.06 & 0.23 & 8,721 & 0.12 & 0.33 & 3,084 & 0.10 & 0.31 & 2,952 & 0.03 & 0.18 & 1,310 & 0.05 & 0.21 & 166 & 0.19 & 0.39 \\
\hline INTDECR & 26,264 & 0.16 & 0.37 & 8,721 & 0.46 & 0.50 & 3,084 & 0.08 & 0.27 & 2,952 & 0.28 & 0.45 & 1,310 & 0.62 & 0.48 & 166 & 0.13 & 0.33 \\
\hline TICKER & 26,264 & 0.73 & 0.45 & 8,721 & 0.75 & 0.44 & 3,084 & 0.85 & 0.36 & 2,952 & 0.74 & 0.44 & 1,310 & 0.73 & 0.45 & 166 & 0.87 & 0.33 \\
\hline Loan Maturity (Month) & 25,050 & 45.27 & 25.27 & 8,629 & 52.13 & 20.30 & 3,075 & 41.57 & 23.35 & 2,906 & 61.69 & 23.45 & 1,297 & 61.12 & 16.98 & 165 & 54.30 & 19.95 \\
\hline Log (Facility Amount) & 26,264 & 18.29 & 1.65 & 8,721 & 18.27 & 1.27 & 3,084 & 19.92 & 1.03 & 2,952 & 18.70 & 1.31 & 1,310 & 18.53 & 1.23 & 166 & 20.06 & 1.06 \\
\hline Facility Amount (\$M) & 26,264 & 285 & 719 & 8,721 & 183 & 371 & 3,084 & 774 & 1,339 & 2,952 & 337 & 820 & 1,310 & 246 & 563 & 166 & 1,1078 & 2,057 \\
\hline REVOLVER & 26,264 & 0.59 & 0.49 & 8,721 & 0.70 & 0.46 & 3,084 & 0.60 & 0.49 & 2,952 & 0.36 & 0.48 & 1,310 & 0.64 & 0.48 & 166 & 0.72 & 0.45 \\
\hline SYND & 26,264 & 0.88 & 0.32 & 8,721 & 0.94 & 0.23 & 3,084 & 0.99 & 0.10 & 2,952 & 0.98 & 0.15 & 1,310 & 0.98 & 0.14 & 166 & 0.99 & 0.08 \\
\hline SECURE & 26,264 & 0.54 & 0.50 & 8,721 & 0.74 & 0.44 & 3,084 & 0.16 & 0.37 & 2,952 & 0.83 & 0.38 & 1,310 & 0.94 & 0.24 & 166 & 0.23 & 0.43 \\
\hline SECUREDMISS & 26,264 & 0.30 & 0.46 & 8,721 & 0.10 & 0.30 & 3,084 & 0.23 & 0.42 & 2,952 & 0.11 & 0.31 & 1,310 & 0.04 & 0.20 & 166 & 0.32 & 0.47 \\
\hline Market Size (\$M) & 26,264 & 3,719 & 13,931 & 8,721 & 1,080 & 2,975 & 3,084 & 8,366 & 14,554 & 2,952 & 3,088 & 10,401 & 1,310 & 1,610 & 3,114 & 166 & 14,757 & 27,137 \\
\hline ROA & 26,264 & 0.02 & 0.05 & 8,721 & 0.02 & 0.03 & 3,084 & 0.03 & 0.03 & 2,952 & 0.02 & 0.03 & 1,310 & 0.02 & 0.03 & 166 & 0.03 & 0.03 \\
\hline Leverage & 26,264 & 0.60 & 0.50 & 8,721 & 0.57 & 0.25 & 3,084 & 0.63 & 0.16 & 2,952 & 0.67 & 0.27 & 1,310 & 0.67 & 0.28 & 166 & 0.65 & 0.19 \\
\hline MB & 26,264 & 1.17 & 1.87 & 8,721 & 1.17 & 1.14 & 3,084 & 1.09 & 0.99 & 2,952 & 1.02 & 1.02 & 1,310 & 0.99 & 0.98 & 166 & 1.30 & 1.24 \\
\hline Rating & 17,639 & 3.40 & 1.84 & 5,952 & 3.11 & 1.63 & 2,609 & 4.41 & 1.70 & 2,042 & 3.19 & 1.66 & 886 & 2.99 & 1.53 & 135 & 4.52 & 1.90 \\
\hline ZScore & 26,264 & 2.40 & 4.76 & 8,721 & 2.63 & 3.57 & 3,084 & 2.01 & 1.89 & 2,952 & 1.90 & 3.40 & 1,310 & 1.84 & 3.51 & 166 & 2.40 & 2.35 \\
\hline Volatility & 26,264 & 3.56 & 2.45 & 8,721 & 3.36 & 1.77 & 3,084 & 2.16 & 1.06 & 2,952 & 3.14 & 1.72 & 1,310 & 3.25 & 1.74 & 166 & 2.29 & 1.26 \\
\hline
\end{tabular}


Panel B: observations that are both ACCPPC and INTINCR and observations that are both ACCPPC and INTDECR.

\begin{tabular}{|c|c|c|c|c|c|c|c|c|c|c|c|c|}
\hline & \multicolumn{6}{|c|}{ Pooled Sample } & \multicolumn{6}{|c|}{ Matched Sample } \\
\hline & \multicolumn{3}{|c|}{ ACCPPC and INTINCR } & \multicolumn{3}{|c|}{ ACCPPC and INTDECR } & \multicolumn{3}{|c|}{ ACCPPC and INTINCR } & \multicolumn{3}{|c|}{ ACCPPC and INTDECR } \\
\hline & Number & Mean & Std. & Number & Mean & Std. & Number & Mean & Std. & Number & Mean & Std. \\
\hline ALLINDRAWN & 1,064 & 122.87 & 78.55 & 3,981 & 236.88 & 92.22 & 63 & 174.92 & 94.56 & 818 & 272.99 & 77.34 \\
\hline PPC & 1,064 & 1.00 & 0.00 & 3,981 & 1.00 & 0.00 & 63 & 1.00 & 0.00 & 818 & 1.00 & 0.00 \\
\hline АССРPC & 1,064 & 1.00 & 0.00 & 3,981 & 1.00 & 0.00 & 63 & 1.00 & 0.00 & 818 & 1.00 & 0.00 \\
\hline DEВTPPC & 1,064 & 0.02 & 0.14 & 3,981 & 0.01 & 0.09 & 63 & 0.00 & 0.00 & 818 & 0.00 & 0.00 \\
\hline INTINCR & 1,064 & 1.00 & 0.00 & 3,981 & 0.00 & 0.00 & 63 & 1.00 & 0.00 & 818 & 0.00 & 0.00 \\
\hline INTDECR & 1,064 & 0.00 & 0.00 & 3,981 & 1.00 & 0.00 & 63 & 0.00 & 0.00 & 818 & 1.00 & 0.00 \\
\hline TICKER & 1,064 & 0.81 & 0.39 & 3,981 & 0.71 & 0.46 & 63 & 0.76 & 0.43 & 818 & 0.73 & 0.45 \\
\hline Loan Maturity (Month) & 1,044 & 48.73 & 20.97 & 3,933 & 53.29 & 21.90 & 61 & 55.82 & 17.64 & 810 & 63.22 & 16.79 \\
\hline Log (Facility Amount) & 1,064 & 18.34 & 1.24 & 3,981 & 17.98 & 1.31 & 63 & 18.61 & 1.28 & 818 & 18.43 & 1.29 \\
\hline Facility Amount (\$M) & 1,064 & 184 & 269 & 3,981 & 164 & 443 & 63 & 308 & 531 & 818 & 256 & 671 \\
\hline REVOLVER & 1,064 & 0.78 & 0.42 & 3,981 & 0.65 & 0.48 & 63 & 0.71 & 0.46 & 818 & 0.59 & 0.49 \\
\hline SYND & 1,064 & 0.93 & 0.26 & 3,981 & 0.92 & 0.28 & 63 & 1.00 & 0.00 & 818 & 0.98 & 0.15 \\
\hline SECURE & 1,064 & 0.61 & 0.49 & 3,981 & 0.82 & 0.39 & 63 & 0.81 & 0.40 & 818 & 0.95 & 0.22 \\
\hline SECUREDMISS & 1,064 & 0.11 & 0.32 & 3,981 & 0.09 & 0.29 & 63 & 0.13 & 0.34 & 818 & 0.04 & 0.19 \\
\hline Market Size (\$M) & 1,064 & 1,528 & 4,118 & 3,981 & 886 & 2,564 & 63 & 1,787 & 2,260 & 818 & 1,775 & 3,582 \\
\hline ROA & 1,064 & 0.03 & 0.03 & 3,981 & 0.02 & 0.04 & 63 & 0.03 & 0.04 & 818 & 0.02 & 0.03 \\
\hline Leverage & 1,064 & 0.47 & 0.24 & 3,981 & 0.58 & 0.28 & 63 & 0.63 & 0.31 & 818 & 0.67 & 0.28 \\
\hline MB & 1,064 & 1.51 & 1.24 & 3,981 & 1.16 & 1.19 & 63 & 1.28 & 0.97 & 818 & 0.99 & 1.01 \\
\hline Rating & 814 & 3.43 & 1.61 & 2,444 & 2.92 & 1.56 & 45 & 3.60 & 1.60 & 514 & 2.95 & 1.43 \\
\hline ZScore & 1,064 & 3.94 & 4.65 & 3,981 & 2.53 & 3.86 & 63 & 2.63 & 3.62 & 818 & 1.90 & 3.97 \\
\hline Volatility & 1,064 & 3.10 & 1.52 & 3,981 & 3.59 & 1.99 & 63 & 2.93 & 1.37 & 818 & 3.30 & 1.83 \\
\hline
\end{tabular}


Panel C: observations that are both DEBTPPC and INTINCR and observations that are both DEBTPPC and INTDECR.

\begin{tabular}{|c|c|c|c|c|c|c|c|c|c|c|c|c|}
\hline & \multicolumn{6}{|c|}{ Pooled Sample } & \multicolumn{6}{|c|}{ Matched Sample } \\
\hline & \multicolumn{3}{|c|}{ DEBTPPC and INTINCR } & \multicolumn{3}{|c|}{ DEBTPPC and INTDECR } & \multicolumn{3}{|c|}{ DEBTPPC and INTINCR } & \multicolumn{3}{|c|}{ DEBTPPC and INTDECR } \\
\hline & Number & Mean & Std. & Number & Mean & Std. & Number & Mean & Std. & Number & Mean & Std. \\
\hline ALLINDRAWN & 321 & 71.02 & 82.33 & 254 & 198.98 & 106.75 & 31 & 64.35 & 75.10 & 21 & 199.52 & 69.52 \\
\hline PPC & 321 & 1.00 & 0.00 & 254 & 1.00 & 0.00 & 31 & 1.00 & 0.00 & 21 & 1.00 & 0.00 \\
\hline ACСРPC & 321 & 0.07 & 0.25 & 254 & 0.12 & 0.32 & 31 & 0.00 & 0.00 & 21 & 0.00 & 0.00 \\
\hline DEBTPPC & 321 & 1.00 & 0.00 & 254 & 1.00 & 0.00 & 31 & 1.00 & 0.00 & 21 & 1.00 & 0.00 \\
\hline INTINCR & 321 & 1.00 & 0.00 & 254 & 0.00 & 0.00 & 31 & 1.00 & 0.00 & 21 & 0.00 & 0.00 \\
\hline INTDECR & 321 & 0.00 & 0.00 & 254 & 1.00 & 0.00 & 31 & 0.00 & 0.00 & 21 & 1.00 & 0.00 \\
\hline TICKER & 321 & 0.84 & 0.37 & 254 & 0.80 & 0.40 & 31 & 0.87 & 0.34 & 21 & 0.86 & 0.36 \\
\hline Loan Maturity (Month) & 320 & 39.10 & 25.09 & 254 & 47.81 & 27.79 & 31 & 58.52 & 19.79 & 21 & 60.62 & 26.76 \\
\hline Log (Facility Amount) & 321 & 19.90 & 1.27 & 254 & 19.50 & 1.15 & 31 & 20.12 & 1.16 & 21 & 20.56 & 1.46 \\
\hline Facility Amount (\$M) & 321 & 1,018 & 2,173 & 254 & 634 & 1,318 & 31 & 1,100 & 1,371 & 21 & 3,096 & 4,980 \\
\hline REVOLVER & 321 & 0.50 & 0.50 & 254 & 0.48 & 0.50 & 31 & 0.71 & 0.46 & 21 & 0.43 & 0.51 \\
\hline SYND & 321 & 0.97 & 0.17 & 254 & 1.00 & 0.06 & 31 & 1.00 & 0.00 & 21 & 1.00 & 0.00 \\
\hline SECURE & 321 & 0.21 & 0.41 & 254 & 0.54 & 0.50 & 31 & 0.13 & 0.34 & 21 & 0.62 & 0.50 \\
\hline SECUREDMISS & 321 & 0.25 & 0.43 & 254 & 0.17 & 0.38 & 31 & 0.45 & 0.51 & 21 & 0.24 & 0.44 \\
\hline Market Size (\$M) & 321 & 12,426 & 21,238 & 254 & 5,162 & 8,602 & 31 & 22,526 & 31,030 & 21 & 18,840 & 19,496 \\
\hline ROA & 321 & 0.03 & 0.04 & 254 & 0.02 & 0.02 & 31 & 0.03 & 0.03 & 21 & 0.03 & 0.60 \\
\hline Leverage & 321 & 0.62 & 0.17 & 254 & 0.70 & 0.22 & 31 & 0.65 & 0.20 & 21 & 0.64 & 0.16 \\
\hline MB & 321 & 1.36 & 1.20 & 254 & 1.05 & 1.18 & 31 & 1.59 & 1.44 & 21 & 1.73 & 1.33 \\
\hline Rating & 281 & 4.76 & 1.66 & 193 & 3.54 & 1.91 & 26 & 5.15 & 1.54 & 18 & 3.72 & 2.74 \\
\hline ZScore & 321 & 2.39 & 2.18 & 254 & 1.67 & 2.18 & 31 & 2.51 & 2.05 & 21 & 2.68 & 1.61 \\
\hline Volatility & 321 & 2.02 & 1.11 & 254 & 2.75 & 1.62 & 31 & 2.05 & 1.81 & 21 & 2.68 & 1.52 \\
\hline
\end{tabular}


Table 5: Percentage of loan facilities with performance pricing covenants. The number of loan facility observations, the percentage with performance pricing covenants (All PPC), without PPC (No PPC), with accounting-based PPC (ACCPPC), with debt-rating-based PPC (DEBTPPC), with interest increasing PPC (INTINCR), and with interest decreasing PPC (INTDECR) are reported for the entire sample, and separately for every year within our sample period.

\begin{tabular}{|c|c|c|c|c|c|c|c|}
\hline Year & $\begin{array}{c}\text { Number of loan } \\
\text { facility observations }\end{array}$ & All PPC & No PPC & АССРPC & DEBTPPC & INTINCR & INTDECR \\
\hline Total & 26,262 & $45.37 \%$ & $54.63 \%$ & $33.21 \%$ & $11.74 \%$ & $5.70 \%$ & $16.49 \%$ \\
\hline 1994 & 1,450 & $27.72 \%$ & $72.28 \%$ & $18.62 \%$ & $8.34 \%$ & $4.41 \%$ & $13.66 \%$ \\
\hline 1995 & 1,331 & $48.01 \%$ & $51.99 \%$ & $36.51 \%$ & $11.34 \%$ & $6.54 \%$ & $23.67 \%$ \\
\hline 1996 & 1,814 & $45.15 \%$ & $54.85 \%$ & $35.89 \%$ & $8.82 \%$ & $3.86 \%$ & $22.77 \%$ \\
\hline 1997 & 2,441 & $45.88 \%$ & $54.12 \%$ & $36.75 \%$ & $9.30 \%$ & $4.26 \%$ & $19.99 \%$ \\
\hline 1998 & 2,130 & $50.94 \%$ & $49.06 \%$ & $43.43 \%$ & $7.42 \%$ & $4.69 \%$ & $22.58 \%$ \\
\hline 1999 & 2,058 & $44.66 \%$ & $55.34 \%$ & $34.89 \%$ & $8.70 \%$ & $4.18 \%$ & $19.83 \%$ \\
\hline 2000 & 2,049 & $41.19 \%$ & $58.81 \%$ & $30.06 \%$ & $10.40 \%$ & $4.29 \%$ & $13.86 \%$ \\
\hline 2001 & 1,864 & $41.68 \%$ & $58.32 \%$ & $26.39 \%$ & $14.32 \%$ & $4.56 \%$ & $14.06 \%$ \\
\hline 2002 & 1,784 & $43.50 \%$ & $56.50 \%$ & $27.91 \%$ & $15.13 \%$ & $4.93 \%$ & $13.23 \%$ \\
\hline 2003 & 1,668 & $45.80 \%$ & $54.20 \%$ & $32.85 \%$ & $12.29 \%$ & $5.70 \%$ & $13.25 \%$ \\
\hline 2004 & 1,816 & $48.95 \%$ & $51.05 \%$ & $32.27 \%$ & $16.24 \%$ & $6.99 \%$ & $12.89 \%$ \\
\hline 2005 & 1,687 & $54.48 \%$ & $45.52 \%$ & $36.16 \%$ & $17.84 \%$ & $8.24 \%$ & $14.40 \%$ \\
\hline 2006 & 1,526 & $50.33 \%$ & $49.67 \%$ & $35.91 \%$ & $14.61 \%$ & $9.31 \%$ & $13.89 \%$ \\
\hline 2007 & 1,534 & $43.02 \%$ & $56.98 \%$ & $30.44 \%$ & $12.97 \%$ & $7.17 \%$ & $12.84 \%$ \\
\hline 2008 & 786 & $53.05 \%$ & $46.95 \%$ & $41.98 \%$ & $10.56 \%$ & $10.81 \%$ & $14.76 \%$ \\
\hline 2009 & 324 & $36.11 \%$ & $63.89 \%$ & $24.38 \%$ & $9.88 \%$ & $8.02 \%$ & $6.79 \%$ \\
\hline
\end{tabular}


Table 6: Difference of means tests, pooled sample. We present the difference of the mean variable value between those loan facilities without PPCs and those with, and calculate the Student's T-statistic and Wilcoxon Signed Rank statistic (Normal Approximation). The sample includes all the loans in the Deal Scan sample during 1994-2010 which belong to non-financial non-utility US firms with available accounting and stock price information. Variable definitions are presented in Table 3.

\begin{tabular}{lrrrrrrr}
\hline & $\begin{array}{l}\text { Without } \\
\text { PPC }\end{array}$ & \multicolumn{1}{l}{$\begin{array}{l}\text { With } \\
\text { PPC }\end{array}$} & $\begin{array}{c}\text { Mean } \\
\text { Without } \\
\text { PPC) }\end{array}$ & $\begin{array}{c}\text { Mean } \\
\text { (With PPC) }\end{array}$ & $\begin{array}{c}\text { Mean } \\
\text { difference }\end{array}$ & \multicolumn{1}{c}{ T-stat } & $\begin{array}{c}\text { Wilcoxon } \\
\text { Statistic (Z) }\end{array}$ \\
\hline ALLINDRAWN & 14,349 & 11,915 & 234.428 & 168.772 & 65.656 & $36.553 * * *$ & $-30.894 * * *$ \\
Facility Amount (\$M) & 14,349 & 11,915 & 248.073 & 329.260 & -81.187 & $-9.127 * * *$ & $31.311 * * *$ \\
Leverage & 14,349 & 11,915 & 0.620 & 0.581 & 0.038 & $6.171 * * *$ & $-6.599 * * *$ \\
MB & 14,349 & 11,915 & 1.195 & 1.146 & 0.049 & $2.109 * *$ & $11.502 * * *$ \\
Market Size (\$M) & 14,349 & 11,915 & $4,394.240$ & $2,906.739$ & $1,487.502$ & $8.627 * * *$ & $20.804 * * *$ \\
ROA & 14,349 & 11,915 & 0.011 & 0.024 & -0.013 & $-21.900^{* * *}$ & $23.431 * * *$ \\
REVOLVER & 14,349 & 11,915 & 0.510 & 0.676 & -0.165 & $-27.450 * * *$ & $27.065 * * *$ \\
SECURE & 14,349 & 11,915 & 0.489 & 0.602 & -0.114 & $-18.499 * * *$ & $18.380^{* * * *}$ \\
SECUREDMISS & 14,349 & 11,915 & 0.435 & 0.132 & 0.303 & $56.672 * * *$ & $-53.496 * * *$ \\
SYND & 14,349 & 11,915 & 0.824 & 0.954 & -0.129 & $-33.129 * * *$ & $32.459 * * *$ \\
Loan Maturity (Month) & 13,239 & 11,811 & 41.753 & 49.217 & -7.464 & $-23.599 * * *$ & $26.260 * * *$ \\
ZScore & 14,349 & 11,915 & 2.354 & 2.465 & -0.111 & $-1.879 *$ & $16.588 * * *$ \\
Rating & 9,045 & 8,594 & 3.320 & 3.490 & -0.170 & $-6.117 * * *$ & $7.787 * * *$ \\
Volatility & 14,349 & 11,915 & 3.959 & 3.081 & 0.878 & $29.406 * * *$ & $-25.627 * * *$
\end{tabular}

$* * *, * *$, and $*$ indicate statistical significance at the $0.01,005$, and 0.10 level. 
Table 7: Difference of means tests, matched sample. We present separately the difference of the mean variable value between those loan facilities without PPCs and those with for the matched pair sample where one element is an accounting-based performance pricing covenant (ACCPPC); the corresponding debt-rating-based performance pricing covenant (DEBTPPC) case; the interest increasing (INTINCR) case; and the interest decreasing (INTDECR) case. We calculate the Student's T-statistic and Wilcoxon Signed Rank (Normal Approximation) statistic. Variable definitions are presented in Table 3

\begin{tabular}{|c|c|c|c|c|c|c|}
\hline Variable & $\begin{array}{c}\text { Number } \\
\text { (Pairs) }\end{array}$ & Without PPC & With PPC & Mean Difference & T-Stat & Wilcoxon Statistic \\
\hline \multicolumn{7}{|l|}{ Panel A: All PPC } \\
\hline ALLINDRAWN & 1,476 & 280.746 & 233.042 & 47.704 & $10.606 * * *$ & $10.396 * * *$ \\
\hline Facility Amount (\$M) & 1,476 & 331.354 & 342.476 & -11.122 & -0.368 & $1.379 *$ \\
\hline Leverage & 1,476 & 0.668 & 0.668 & 0.000 & N/A & N/A \\
\hline MB & 1,476 & 1.024 & 1.024 & 0.000 & N/A & N/A \\
\hline Market Size (\$M) & 1,476 & $3,088.352$ & $3,088.352$ & 0.000 & N/A & N/A \\
\hline ROA & 1,476 & 0.021 & 0.021 & 0.000 & N/A & N/A \\
\hline REVOLVER & 1,476 & 0.076 & 0.650 & -0.575 & $-40.454 * * *$ & $-32.449 * * *$ \\
\hline SECURE & 1,476 & 0.792 & 0.858 & -0.066 & $-4.766 * * *$ & $-4.748 * * *$ \\
\hline SECUREDMISS & 1,476 & 0.144 & 0.074 & 0.070 & $6.178 * * *$ & $6.139 * * *$ \\
\hline SYND & 1,476 & 0.974 & 0.982 & -0.007 & -1.380 & $-1.380 *$ \\
\hline Loan Maturity (Month) & 1,462 & 63.039 & 60.349 & 2.691 & $3.098 * * *$ & $7.948 * * *$ \\
\hline ZScore & 1,476 & 1.899 & 1.899 & 0.000 & N/A & N/A \\
\hline rating & 1,021 & 3.194 & 3.194 & 0.000 & N/A & N/A \\
\hline volatility & 1,476 & 3.143 & 3.143 & 0.000 & N/A & N/A \\
\hline \multicolumn{7}{|l|}{ Panel B: DEBTPPC } \\
\hline ALLINDRAWN & 166 & 110.530 & 95.913 & 14.617 & 1.339 & -0.366 \\
\hline Facility Amount (\$M) & 166 & 856.158 & $1,107.525$ & -251.366 & -1.247 & $2.770 * * *$ \\
\hline Leverage & 166 & 0.652 & 0.652 & 0.000 & N/A & N/A \\
\hline MB & 166 & 1.300 & 1.300 & 0.000 & N/A & N/A \\
\hline
\end{tabular}




\begin{tabular}{|c|c|c|c|c|c|c|}
\hline Market Size (\$M) & 166 & $14,756.590$ & $14,756.590$ & 0.000 & N/A & N/A \\
\hline ROA & 166 & 0.029 & 0.029 & 0.000 & N/A & N/A \\
\hline REVOLVER & 166 & 0.108 & 0.717 & -0.608 & $-14.278 * * *$ & $11.241 * * *$ \\
\hline SECURE & 166 & 0.241 & 0.235 & 0.006 & 0.128 & -0.128 \\
\hline SECUREDMISS & 166 & 0.398 & 0.319 & 0.078 & 1.488 & $-1.485^{*}$ \\
\hline SYND & 166 & 0.976 & 0.994 & -0.018 & -1.352 & $1.347^{*}$ \\
\hline Loan Maturity (Month) & 165 & 32.438 & 54.297 & -21.859 & $-8.093 * * *$ & $-6.895^{* * *}$ \\
\hline ZScore & 166 & 2.401 & 2.401 & 0.000 & N/A & N/A \\
\hline rating & 135 & 4.519 & 4.519 & 0.000 & N/A & N/A \\
\hline volatility & 166 & 2.286 & 2.286 & 0.000 & N/A & $\mathrm{N} / \mathrm{A}$ \\
\hline \multicolumn{7}{|l|}{ Panel C: $A C C P P C$} \\
\hline ALLINDRAWN & 1,310 & 302.315 & 250.419 & 51.896 & $12.043 * * *$ & $11.541 * * *$ \\
\hline Facility Amount (\$M) & 1,310 & 264.852 & 245.531 & 19.320 & 0.950 & $1.990^{* *}$ \\
\hline Leverage & 1,310 & 0.670 & 0.670 & 0.000 & N/A & N/A \\
\hline MB & 1,310 & 0.989 & 0.989 & 0.000 & N/A & N/A \\
\hline Market Size (\$M) & 1,310 & $1,609.782$ & $1,609.782$ & 0.000 & N/A & N/A \\
\hline ROA & 1,310 & 0.021 & 0.021 & 0.000 & N/A & N/A \\
\hline REVOLVER & 1,310 & 0.072 & 0.642 & -0.570 & $-37.892 * * *$ & $-30.457 * * *$ \\
\hline SECURE & 1,310 & 0.862 & 0.937 & -0.076 & $-6.485 * * *$ & $-6.435^{* * * *}$ \\
\hline SECUREDMISS & 1,310 & 0.112 & 0.043 & 0.069 & $6.704 * * *$ & $6.649 * * *$ \\
\hline SYND & 1,310 & 0.974 & 0.980 & -0.006 & -1.045 & -1.044 \\
\hline Loan Maturity (Month) & 1,297 & 66.906 & 61.119 & 5.788 & $6.754 * * *$ & $10.819 * * *$ \\
\hline ZScore & 1,310 & 1.835 & 1.835 & 0.000 & N/A & N/A \\
\hline rating & 886 & 2.992 & 2.992 & 0.000 & N/A & N/A \\
\hline volatility & 1,310 & 3.252 & 3.252 & 0.000 & N/A & N/A \\
\hline
\end{tabular}

Panel D: INTINCR 


\begin{tabular}{|c|c|c|c|c|c|c|}
\hline ALLINDRAWN & 94 & 208.622 & 138.457 & 70.165 & $3.267 * * *$ & $2.432 * * *$ \\
\hline Facility Amount $(\$ M)$ & 94 & 457.651 & 569,316 & $-111,665$ & -0.921 & -0.589 \\
\hline Leverage & 94 & 0.637 & 0.637 & 0.000 & N/A & N/A \\
\hline MB & 94 & 1.378 & 1.378 & 0.000 & N/A & N/A \\
\hline Market Size (\$M) & 94 & $8,626,515$ & $8,626,515$ & 0.000 & N/A & N/A \\
\hline ROA & 94 & 0.030 & 0.030 & 0.000 & N/A & N/A \\
\hline REVOLVER & 94 & 0.213 & 0.713 & -0.500 & $-7.903 * * *$ & $-6.855^{* * *}$ \\
\hline SECURE & 94 & 0.511 & 0.585 & -0.074 & -1.023 & -1.022 \\
\hline SECUREDMISS & 94 & 0.330 & 0.234 & 0.096 & 1.459 & $1.453^{*}$ \\
\hline SYND & 94 & 0.989 & 1.000 & -0.011 & -1.000 & -0.990 \\
\hline Loan Maturity (Month) & 92 & 45.473 & 56.728 & -11.255 & $-3.339 * * *$ & $2.508 * * *$ \\
\hline ZScore & 94 & 2.592 & 2.592 & 0.000 & N/A & N/A \\
\hline rating & 71 & 4.169 & 4.169 & 0.000 & N/A & N/A \\
\hline volatility & 94 & 2.640 & 2.640 & 0.000 & N/A & N/A \\
\hline \multicolumn{7}{|l|}{ Panel E: INTDECR } \\
\hline ALLINDRAWN & 839 & 311.424 & 270.187 & 41.237 & $8.321 * * *$ & $8.090 * * *$ \\
\hline Facility Amount $(\$ M)$ & 839 & 336.055 & 326.856 & 9.199 & 0.190 & $2.721 * * *$ \\
\hline Leverage & 839 & 0.669 & 0.669 & 0.000 & N/A & N/A \\
\hline MB & 839 & 1.007 & 1.007 & 0.000 & N/A & N/A \\
\hline Market Size (\$M) & 839 & $2,201.807$ & $2,201.807$ & 0.000 & N/A & N/A \\
\hline $\mathrm{ROA}$ & 839 & 0.020 & 0.020 & 0.000 & N/A & N/A \\
\hline REVOLVER & 839 & 0.070 & 0.590 & -0.520 & $-27.138 * * *$ & $-22.626^{* * *}$ \\
\hline SECURE & 839 & 0.884 & 0.943 & -0.058 & $-4.278 * * *$ & $-4.256^{* * *}$ \\
\hline SECUREDMISS & 839 & 0.093 & 0.042 & 0.051 & $4.208 * * *$ & $4.187^{* * *}$ \\
\hline SYND & 839 & 0.974 & 0.977 & -0.004 & -0.474 & -0.474 \\
\hline Loan Maturity (Month) & 831 & 67.253 & 63.158 & 4.096 & $3.636 * * *$ & $8.068 * * *$ \\
\hline ZScore & 839 & 1.917 & 1.917 & 0.000 & N/A & N/A \\
\hline
\end{tabular}




\begin{tabular}{llllll} 
rating & 532 & 2.979 & 2.979 & 0.000 & N/A \\
volatility & 839 & 3.286 & 3.286 & 0.000 & N/A \\
\hline
\end{tabular}

$* * *, * *$, and $*$ indicate statistical significance at the $0.01,005$, and 0.10 level. 
Table 8: Counting tests, matched sample. The number of times that the facility without a performance pricing covenant (PPC) of a matched pair has a higher, identical, or lower value for the rates all in spread (ALLINDRAWN) variable relative to the facility with a PPC is reported. These values are reported for all matched pairs (Panel A), matched pairs where the facility with a PPC is an accounting-based PPC (ACCPPC), matched pairs where the facility with a PPC is a debt-rating-based PPC (DEBTPPC), matched pairs where the facility with a PPC is interest increasing (INTINCR), and matched pairs where the facility with a PPC is a interest decreasing (INTDECR). These results are reported for all rating categories, and are reported separately for matched pairs associated with borrower with ratings of A, B, C, D, and unrated. We also report the percentage higher, identical, lower, and the number of paired observations for each sample. The significance levels at which a one-tailed proportion test suggests that loans with no PPC have spreads that are higher than/identical to or absolutely higher than the spreads of loans with PPC are reported. ***, **, and * respectively, and represent significance at $1 \%, 5 \%$ and $10 \%$ levels.

\begin{tabular}{|c|c|c|c|c|c|c|c|c|c|c|c|c|}
\hline & \multicolumn{2}{|c|}{ All } & \multicolumn{2}{|c|}{ A-rated } & \multicolumn{2}{|c|}{ B-rated } & \multicolumn{2}{|c|}{ C-rated } & \multicolumn{2}{|c|}{ D-rated } & \multicolumn{2}{|c|}{ Unrated } \\
\hline & Pairs & $\%$ & Pairs & $\%$ & Pairs & Pairs & $\%$ & $\%$ & Pairs & $\%$ & Pairs & $\%$ \\
\hline Panel A: All perfor & enants & atcheds & nple & & & & & & & & & \\
\hline Higher & 909 & $62 \%$ & 27 & $38 \%$ & 394 & $58 \%$ & 86 & $62 \%$ & 83 & $65 \%$ & 319 & $70 \%$ \\
\hline Identical & 350 & $24 \%$ & 40 & $56 \%$ & 176 & $26 \%$ & 28 & $20 \%$ & 25 & $20 \%$ & 81 & $18 \%$ \\
\hline higher or identical & & $* * *$ & & $* * *$ & & $* * *$ & & $* * *$ & & $* * *$ & & $* * *$ \\
\hline absolutely higher & & $* * *$ & & & & $* * *$ & & $* * *$ & & $* * *$ & & $* * *$ \\
\hline
\end{tabular}

Panel B: Accounting-based performance pricing covenants matched sample

\begin{tabular}{lrr|rr|rr|rr|r|r|r|r} 
Lower & 189 & $14 \%$ & 5 & $15 \%$ & 96 & $16 \%$ & 24 & $18 \%$ & 18 & $15 \%$ & 46 & $11 \%$ \\
Higher & 866 & $66 \%$ & 21 & $62 \%$ & 371 & $62 \%$ & 81 & $61 \%$ & 81 & $68 \%$ & 312 & $74 \%$ \\
Identical & 255 & $19 \%$ & 8 & $24 \%$ & 133 & $22 \%$ & 28 & $21 \%$ & 20 & $17 \%$ & 66 & $16 \%$ \\
Total & 1310 & $100 \%$ & 34 & $100 \%$ & 600 & $100 \%$ & 133 & $100 \%$ & 119 & $100 \%$ & 424 & $100 \%$ \\
higher or identical & & $* * *$ & & $* * *$ & & $* * *$ & & $* * *$ & $* *$ & $* *$ \\
absolutely higher & & $* * *$ & & $*$ & & $* * *$ & & $* * *$ & & $* * *$ & \\
\hline
\end{tabular}

Panel C: Debt-rating-based performance pricing covenants matched sample

\begin{tabular}{|c|c|c|c|c|c|c|c|c|c|c|c|c|}
\hline Lower & 28 & $17 \%$ & 0 & $0 \%$ & 17 & $20 \%$ & 0 & $0 \%$ & 2 & $22 \%$ & 9 & $29 \%$ \\
\hline Identical & 95 & $57 \%$ & 32 & $84 \%$ & 43 & $52 \%$ & 0 & $0 \%$ & 5 & $56 \%$ & 15 & $48 \%$ \\
\hline
\end{tabular}




\begin{tabular}{ll|l|l|l|l|l|}
$\begin{array}{l}\text { higher or identical } \\
\text { absolutely higher }\end{array}$ & $* * *$ & $* * *$ & $* * *$ & $* * *$ & $* *$ & $* * *$ \\
\hline
\end{tabular}

Panel D: Interest increasing performance pricing covenants matched sample

\begin{tabular}{lrr|rr|rr|rr|rr|rr|} 
Lower & 13 & $14 \%$ & 2 & $13 \%$ & 4 & $9 \%$ & 1 & $17 \%$ & 0 & $0 \%$ & 6 & $26 \%$ \\
Higher & 51 & $54 \%$ & 5 & $33 \%$ & 28 & $60 \%$ & 5 & $83 \%$ & 2 & $67 \%$ & 11 & $48 \%$ \\
Identical & 30 & $32 \%$ & 8 & $53 \%$ & 15 & $32 \%$ & 0 & $0 \%$ & 1 & $33 \%$ & 6 & $26 \%$ \\
Total & 94 & $100 \%$ & 15 & $100 \%$ & 47 & $100 \%$ & 6 & $100 \%$ & 3 & $100 \%$ & 23 & $100 \%$ \\
higher or identical & & $* * *$ & & $* * *$ & & $* * *$ & & $* *$ & & $* *$ & $* * *$ \\
absolutely higher & & & & & & $*$ & & $* *$ & & & $* * *$ \\
\hline
\end{tabular}

Panel E: Interest decreasing performance pricing covenants matched sample

\begin{tabular}{lrr|rr|rr|rr|r|r|r|r|r} 
Lower & 139 & $17 \%$ & 2 & $13 \%$ & 74 & $20 \%$ & 14 & $21 \%$ & 16 & $21 \%$ & 33 & $11 \%$ \\
Higher & 530 & $63 \%$ & 8 & $53 \%$ & 217 & $58 \%$ & 36 & $54 \%$ & 44 & $57 \%$ & 225 & $73 \%$ \\
Identical & 170 & $20 \%$ & 5 & $33 \%$ & 82 & $22 \%$ & 17 & $25 \%$ & 17 & $22 \%$ & 49 & $16 \%$ \\
Total & 839 & $100 \%$ & 15 & $100 \%$ & 373 & $100 \%$ & 67 & $100 \%$ & 77 & $100 \%$ & 307 & $100 \%$ \\
higher or identical & & $* * *$ & & $* * *$ & & $* * *$ & & $* * *$ & $* *$ & $* * *$ \\
absolutely higher & & $* * *$ & & & & $* * *$ & & & & $* * *$ \\
\hline
\end{tabular}


Table 9: Correlations. This table provides correlation coefficients between variables for the pooled sample. Variable definitions are presented in Table 3.

\begin{tabular}{|c|c|c|c|c|c|c|c|c|c|c|c|c|c|c|c|c|c|c|c|c|}
\hline & & [1] & [2] & [3] & [4] & [5] & [6] & [7] & [8] & [9] & {$[10]$} & [11] & [12] & [13] & [14] & [15] & [16] & [17] & [18] & [19] \\
\hline$\overline{\mathrm{PPC}}$ & {$[1]$} & & & & & & & & & & & & & & & & & & & \\
\hline ACCPPC & {$[2]$} & 0.77 & & & & & & & & & & & & & & & & & & \\
\hline DEBTPPC & [3] & 0.40 & -0.21 & & & & & & & & & & & & & & & & & \\
\hline INTINCR & [4] & 0.27 & 0.20 & 0.07 & & & & & & & & & & & & & & & & \\
\hline INTDECR & [5] & 0.49 & 0.55 & -0.08 & -0.11 & & & & & & & & & & & & & & & \\
\hline TICKER & [6] & 0.09 & 0.03 & 0.10 & 0.05 & -0.02 & & & & & & & & & & & & & & \\
\hline Loan Maturity (Month) & [7] & 0.15 & 0.20 & -0.05 & 0.01 & 0.14 & -0.05 & & & & & & & & & & & & & \\
\hline Log (Facility Amount) & {$[8]$} & 0.22 & -0.01 & 0.36 & 0.06 & -0.06 & 0.13 & 0.13 & & & & & & & & & & & & \\
\hline Facility Amount & [9] & 0.06 & -0.10 & 0.25 & 0.03 & -0.06 & 0.07 & -0.01 & 0.51 & & & & & & & & & & & \\
\hline REVOLVER & {$[10]$} & 0.17 & 0.16 & 0.01 & 0.06 & 0.05 & 0.01 & -0.01 & -0.04 & -0.06 & & & & & & & & & & \\
\hline SYND & [11] & 0.20 & 0.13 & 0.12 & 0.04 & 0.06 & 0.08 & 0.18 & 0.49 & 0.12 & -0.05 & & & & & & & & & \\
\hline SECURE & [12] & 0.11 & 0.29 & -0.28 & 0.00 & 0.23 & -0.06 & 0.14 & -0.34 & -0.19 & 0.01 & -0.14 & & & & & & & & \\
\hline SECUREDMISS & {$[13]$} & -0.33 & -0.31 & -0.05 & -0.08 & -0.20 & 0.00 & -0.09 & 0.17 & 0.08 & -0.07 & 0.09 & -0.71 & & & & & & & \\
\hline Market_size & [14] & -0.05 & -0.13 & 0.12 & 0.00 & -0.08 & 0.06 & -0.07 & 0.33 & 0.45 & -0.08 & 0.08 & -0.21 & 0.17 & & & & & & \\
\hline Profitability & [15] & -0.01 & 0.01 & -0.02 & 0.00 & -0.02 & -0.01 & -0.01 & -0.01 & 0.00 & 0.00 & 0.00 & -0.01 & 0.01 & 0.00 & & & & & \\
\hline Leverage & [16] & -0.04 & -0.05 & 0.02 & -0.04 & -0.01 & -0.02 & 0.02 & 0.09 & 0.03 & -0.05 & 0.07 & 0.02 & 0.01 & -0.01 & 0.00 & & & & \\
\hline MB & [17] & -0.01 & 0.00 & -0.02 & 0.03 & -0.01 & 0.02 & -0.04 & -0.08 & -0.01 & 0.01 & -0.08 & -0.02 & 0.00 & 0.13 & -0.01 & 0.42 & & & \\
\hline Rating & [18] & 0.05 & -0.11 & 0.23 & 0.04 & -0.10 & 0.12 & -0.05 & 0.35 & 0.22 & -0.02 & 0.14 & -0.37 & 0.21 & 0.28 & 0.00 & -0.03 & 0.08 & & \\
\hline ZScore & [19] & 0.01 & 0.03 & -0.03 & 0.05 & 0.01 & 0.01 & -0.04 & -0.09 & -0.03 & 0.04 & -0.09 & -0.04 & 0.00 & 0.08 & 0.00 & -0.48 & 0.33 & 0.08 & \\
\hline Volatility & [20] & -0.18 & -0.06 & -0.21 & -0.06 & 0.00 & -0.08 & -0.14 & -0.43 & -0.19 & 0.01 & -0.24 & 0.28 & -0.14 & -0.15 & 0.00 & 0.09 & -0.01 & -0.37 & -0.06 \\
\hline
\end{tabular}


Table 10: Regression Tests, Spread Analysis. ALLINDRAWN is the dependent variable. It is the basis point coupon spread over LIBOR plus the annual fee and upfront fee, stated at the time of loan initiation. ALLINDRAWN is regressed on dichotomous variables for Accounting-based PPC (ACCPCC) and Rating-based PPC (DEBTPPC), and on control variables including loan characteristics (Models 1-4), borrower accounting and risk ratios (Model 2), borrower Altman's Z Score (Model 3), and borrower credit rating (Model 4). Coefficients for year and covenant dummies are not reported. Each panel then provides estimates of each of these models on different samples. Panel A includes all the loans in the Deal Scan sample during 1994-2010 which belong to non-financial non-utility US firms with available accounting and stock price information. This sample is then restricted to only matched loans in Panels B to E. Matched loans are loans that belong to the same loan package differ in terms of having a performance pricing covenant. Detailed definitions of the explanatory variables can be found in Table 3.

\begin{tabular}{|c|c|c|c|c|c|c|c|c|}
\hline Variable & Estimate & StdErr & Estimate & StdErr & Estimate & StdErr & Estimate & StdErr \\
\hline \multicolumn{9}{|l|}{ Panel A: Pooled Sample } \\
\hline & \multicolumn{2}{|c|}{ Model (1) } & \multicolumn{2}{|c|}{ Model (2) } & \multicolumn{2}{|c|}{ Model (3) } & \multicolumn{2}{|c|}{ Model (4) } \\
\hline ACCPPC & $-50.21 * * *$ & 4.18 & $-53.61 * * *$ & 3.88 & $-56.67 * * *$ & 3.96 & $-58.84 * * *$ & 4.58 \\
\hline DEBTPPC & -24.99 & 22.55 & -8.74 & 20.89 & -13.38 & 21.36 & -11.02 & 23.51 \\
\hline Log (Facility Amount) & $-25.53 * * *$ & 0.54 & $-8.8 * * *$ & 0.70 & $-5.94 * * *$ & 0.67 & $-3.11 * * *$ & 0.79 \\
\hline Loan Maturity (months) & $0.45 * * *$ & 0.03 & $0.42 * * *$ & 0.03 & $0.36 * * *$ & 0.03 & $0.37 * * *$ & 0.04 \\
\hline Syndicated & -0.09 & 2.74 & -1.38 & 2.56 & $-7.11 * * *$ & 2.60 & -2.55 & 3.34 \\
\hline Secured & $111.41 * * *$ & 2.36 & $82.31 * * *$ & 2.23 & $89.29 * * *$ & 2.27 & $83.83 * * *$ & 2.59 \\
\hline Missing Secured Status & $10.72 * * *$ & 2.49 & $10.74 * * *$ & 2.31 & $12.38 * * *$ & 2.36 & $7.45 * * *$ & 2.64 \\
\hline Revolver & $-32.09 * * *$ & 1.53 & $-39.85 * * *$ & 1.44 & $-41.02 * * *$ & 1.47 & $-44.11 * * *$ & 1.73 \\
\hline ROA & & & $-226.53 * * *$ & 15.72 & & & & \\
\hline Leverage & & & $22.21 * * *$ & 1.66 & & & & \\
\hline Market to Book & & & $-5.53 * * *$ & 0.46 & & & & \\
\hline Volatility & & & $9.08 * * *$ & 0.37 & & & & \\
\hline $\log ($ Size $)$ & & & $-16.13 * * *$ & 0.63 & $-24.76 * * *$ & 0.55 & $-22.36 * * *$ & 0.67 \\
\hline Altman's Z Score & & & & & $-1.5 * * *$ & 0.15 & & \\
\hline Rated Indicator & & & $-13.69 * * *$ & 1.58 & $-18 * * *$ & 1.60 & & \\
\hline Rating & & & & & & & $-12.94 * * *$ & 0.52 \\
\hline Intercept & $832.37 * * *$ & 11.63 & $693.13 * * *$ & 11.90 & $824.1 * * *$ & 11.1 & $777.75 * * *$ & 12.65 \\
\hline \multicolumn{9}{|l|}{ Covenant Fixed Effect } \\
\hline \multicolumn{9}{|l|}{ Year Fixed Effect } \\
\hline Adjusted R-Square & 0.39 & & 0.48 & & 0.46 & & 0.49 & \\
\hline
\end{tabular}




\begin{tabular}{|c|c|c|c|c|c|c|c|c|}
\hline \multirow{2}{*}{$\begin{array}{l}\text { Number of Observations } \\
\text { Variable }\end{array}$} & \multicolumn{2}{|l|}{25,050} & \multicolumn{2}{|l|}{25,050} & \multicolumn{2}{|l|}{25,050} & \multicolumn{2}{|l|}{16,920} \\
\hline & Estimate & StdErr & Estimate & StdErr & Estimate & StdErr & Estimate & StdErr \\
\hline \multicolumn{9}{|c|}{ Panel B: Matched Sample ACCPCC } \\
\hline & \multicolumn{2}{|c|}{ Model (1) } & \multicolumn{2}{|c|}{ Model (2) } & \multicolumn{2}{|c|}{ Model (3) } & \multicolumn{2}{|c|}{ Model (4) } \\
\hline АCCPPC & $-59.50 * * *$ & 12.63 & $-84.72 * * *$ & 12.17 & $-70.59 * * *$ & 12.46 & $-61.31 * * *$ & 15.64 \\
\hline Log (Facility Amount) & $-20.97 * * *$ & 1.68 & $-5.59 * * *$ & 2.16 & $-7.55 * * *$ & 2.16 & $-9.9 * * *$ & 2.6 \\
\hline Loan Maturity (months) & -0.090 & 0.11 & -0.09 & 0.10 & -0.07 & 0.10 & $-0.31 * *$ & 0.13 \\
\hline Syndicated & $31.45 * *$ & 14.75 & $38.25 * * *$ & 14.13 & $29.75 * *$ & 14.52 & $52.57 * * *$ & 18.08 \\
\hline Secured & $103.83 * * *$ & 13.28 & $84.44 * * *$ & 12.85 & $96.4 * * *$ & 13.13 & $106.76 * * *$ & 14.85 \\
\hline Missing Secured Status & $37.15^{* *}$ & 14.86 & $35.93 * *$ & 14.26 & $39.16^{* * *}$ & 14.63 & $54.01 * * *$ & 16.83 \\
\hline Revolver & $-25.52 * * *$ & 5.23 & $-23.83 * * *$ & 5.00 & $-24.9 * * *$ & 5.15 & $-37.44 * * *$ & 6.51 \\
\hline ROA & & & $-578.52 * * *$ & 69.84 & & & & \\
\hline Leverage & & & $33.09 * * *$ & 7.15 & & & & \\
\hline Market to Book & & & $4.94 * *$ & 2.31 & & & & \\
\hline Volatility & & & $7.79 * * *$ & 1.38 & & & & \\
\hline Log (Size) & & & $-16.42 * * *$ & 2.09 & $-17.78 * * *$ & 1.86 & $-18.73 * * *$ & 2.33 \\
\hline Altman 's Z Score & & & & & $1.04 *$ & 0.57 & & \\
\hline Rated Indicator & & & 1.87 & 4.40 & -3.02 & 4.46 & & \\
\hline Rating & & & & & & & $-5.71 * * *$ & 1.75 \\
\hline Intercept & $713.57 * * *$ & 40.21 & $615.1 * * *$ & 40.43 & $706.26 * * *$ & 39.77 & $746.83 * * *$ & 50.59 \\
\hline \multicolumn{9}{|l|}{ Covenant Fixed Effect } \\
\hline \multicolumn{9}{|l|}{ Year Fixed Effect } \\
\hline Adjusted R-Square & 0.24 & & 0.31 & & 0.27 & & 0.29 & \\
\hline Number of Observations & 2,579 & & 2,579 & & 2,579 & & 1,738 & \\
\hline
\end{tabular}




\begin{tabular}{|c|c|c|c|c|c|c|c|c|}
\hline Variable & Estimate & StdErr & Estimate & StdErr & Estimate & StdErr & Estimate & StdErr \\
\hline \multicolumn{9}{|c|}{ Panel C: Matched Sample DEBTPPC } \\
\hline & \multicolumn{2}{|c|}{ Model (1) } & \multicolumn{2}{|c|}{ Model (2) } & \multicolumn{2}{|c|}{ Model (3) } & \multicolumn{2}{|c|}{ Model (4) } \\
\hline DEBTPPC & -32.41 & 45.11 & -58.56 & 40.49 & -58.03 & 42.45 & $-132.63 * *$ & 59.27 \\
\hline Log (Facility Amount) & $-11.48 * * *$ & 3.68 & 0.93 & 4.08 & 0.96 & 4.13 & 5.67 & 4.39 \\
\hline Loan Maturity (months) & $1.28 * * *$ & 0.17 & $1.12 * * *$ & 0.16 & $1.26 * * *$ & 0.16 & $1.03 * * *$ & 0.17 \\
\hline Syndicated & -47.49 & 35.18 & -9.99 & 31.95 & -19.52 & 33.34 & -13.62 & 39.79 \\
\hline Secured & $106.55 * * *$ & 11.07 & $92.04 * * *$ & 10.01 & $97.14 * * *$ & 10.47 & $90.15^{* * *}$ & 11.04 \\
\hline Missing Secured Status & $18.82 * *$ & 8.24 & 11.76 & 7.44 & $14.78^{*}$ & 7.73 & 12.19 & 8.07 \\
\hline Revolver & $-48.29 * * *$ & 9.34 & $-42.1 * * *$ & 8.42 & $-45.61 * * *$ & 8.80 & $-32.61 * * *$ & 9.50 \\
\hline ROA & & & $-289.48 * *$ & 139.78 & & & & \\
\hline Leverage & & & 24.21 & 18.48 & & & & \\
\hline Market to Book & & & 3.05 & 3.93 & & & & \\
\hline Volatility & & & $14.65 * * *$ & 2.82 & & & & \\
\hline Log (Size) & & & $-15.36 * * *$ & 3.51 & $-18.01 * * *$ & 3.13 & $-15.31 * * *$ & 2.80 \\
\hline Altman's Z Score & & & & & 0.50 & 1.63 & & \\
\hline Rated Indicator & & & -13.34 & 8.39 & -11.06 & 8.74 & & \\
\hline Rating & & & & & & & $-9.15 * * *$ & 2.22 \\
\hline Intercept & $400.63 * * *$ & 99.35 & $376.46 * * *$ & 89.99 & $447.04 * * *$ & 93.98 & $355.23 * * *$ & 100.72 \\
\hline \multicolumn{9}{|l|}{ Covenant Fixed Effect } \\
\hline \multicolumn{9}{|l|}{ Year Fixed Effect } \\
\hline Adjusted R-Square & 0.65 & & 0.72 & & 0.69 & & 0.70 & \\
\hline Number of Observations & 327 & & 327 & & 327 & & 265 & \\
\hline
\end{tabular}




\begin{tabular}{|c|c|c|c|c|c|c|c|c|}
\hline Variable & Estimate & StdErr & Estimate & StdErr & Estimate & StdErr & Estimate & StdErr \\
\hline \multicolumn{9}{|c|}{ Panel D: Matched Sample INTINCR } \\
\hline & \multicolumn{2}{|c|}{ Model (1) } & \multicolumn{2}{|c|}{ Model (2) } & \multicolumn{2}{|c|}{ Model (3) } & \multicolumn{2}{|c|}{ Model (4) } \\
\hline ACCPPC & $-94.02 *$ & 47.84 & $-149.05 * * *$ & 43.27 & $-154.65 * * *$ & 43.27 & $-153.07 * * *$ & 45.57 \\
\hline DEBTPPC & -5.89 & 32.41 & -12.30 & 28.91 & 0.60 & 28.65 & -13.19 & 30.99 \\
\hline Log (Facility Amount) & $-33.46^{* * *}$ & 7.16 & 4.84 & 10.85 & 8.97 & 9.77 & 8.21 & 11.16 \\
\hline Loan Maturity (months) & 0.62 & 0.49 & 0.52 & 0.44 & 0.38 & 0.44 & 0.59 & 0.48 \\
\hline Syndicated & 10.07 & 127.33 & -34.04 & 114.79 & -36.94 & 113.52 & -49.43 & 115.37 \\
\hline Secured & $111.24 * * *$ & 38.82 & $72 * *$ & 35.03 & $74.06^{* *}$ & 34.74 & $99.78 * *$ & 38.43 \\
\hline Missing Secured Status & 3.4 & 34.50 & -12.33 & 30.39 & -10.94 & 30.54 & 17.05 & 32.41 \\
\hline Revolver & $-51.44 * *$ & 23.32 & $-48.87 * *$ & 20.51 & $-52.44 * *$ & 20.62 & $-45.2 * *$ & 21.54 \\
\hline ROA & & & -307.86 & 251.18 & & & & \\
\hline Leverage & & & $82.28 *$ & 43.74 & & & & \\
\hline Market to Book & & & 6.22 & 12.81 & & & & \\
\hline Volatility & & & 6.07 & 7.99 & & & & \\
\hline Log (Size) & & & $-41.5 * * *$ & 11.68 & $-50.5 * * *$ & 8.33 & $-52.2 * * *$ & 9.95 \\
\hline Altman's Z Score & & & & & -3.41 & 3.10 & & \\
\hline Rated Indicator & & & 14.71 & 22.37 & 16.98 & 21.07 & & \\
\hline Rating & & & & & & & 7.31 & 7.13 \\
\hline Intercept & $945.06 * * *$ & 200.83 & $817.08 * * *$ & 190.55 & $958.78 * * *$ & 180.86 & $940.68 * * *$ & 186.21 \\
\hline \multicolumn{9}{|l|}{ Covenant Fixed Effect } \\
\hline \multicolumn{9}{|l|}{ Year Fixed Effect } \\
\hline Adjusted R-Square & 0.41 & & 0.55 & & 0.54 & & 0.61 & \\
\hline Number of Observations & 185 & & 185 & & 185 & & 140 & \\
\hline
\end{tabular}




\begin{tabular}{|c|c|c|c|c|c|c|c|c|}
\hline Variable & Estimate & StdErr & Estimate & StdErr & Estimate & StdErr & Estimate & StdErr \\
\hline \multicolumn{9}{|c|}{ Panel E: Matched Sample INTDECR } \\
\hline & \multicolumn{2}{|c|}{ Model (1) } & \multicolumn{2}{|c|}{ Model (2) } & \multicolumn{2}{|c|}{ Model (3) } & \multicolumn{2}{|c|}{ Model (4) } \\
\hline ACCPPC & -25.64 & 19.07 & $-42.1 * *$ & 18.39 & $-34.69 *$ & 18.82 & -6.64 & 27.36 \\
\hline DEBTPPC & -73.81 & 91.61 & -57.08 & 88.13 & -62.72 & 90.31 & $-46.68 *$ & 23.91 \\
\hline Log (Facility Amount) & $-18.75^{* * *}$ & 1.86 & $-5.1 * *$ & 2.46 & $-7.44 * * *$ & 2.45 & $-11.79 * * *$ & 3.12 \\
\hline Loan Maturity (months) & -0.03 & 0.12 & -0.09 & 0.11 & -0.07 & 0.12 & $-0.36 * *$ & 0.15 \\
\hline Syndicated & 26.74 & 16.54 & $35.03 * *$ & 16.00 & $27.41^{*}$ & 16.31 & $48.29 * *$ & 22.61 \\
\hline Secured & $48.97 * * *$ & 17.01 & $44.86 * * *$ & 16.41 & $47.15 * * *$ & 16.80 & $65.43 * * *$ & 19.62 \\
\hline Missing Secured Status & -8.14 & 18.83 & -1.67 & 18.20 & -4.81 & 18.62 & 20.01 & 22.11 \\
\hline Revolver & $-16.74 * * *$ & 5.95 & $-13.24 * *$ & 5.72 & $-14.12 * *$ & 5.87 & $-25.69 * * *$ & 7.85 \\
\hline ROA & & & $-297.58 * * *$ & 88.99 & & & & \\
\hline Leverage & & & $17.76^{* *}$ & 8.40 & & & & \\
\hline Market to Book & & & $11.1 * * *$ & 2.63 & & & & \\
\hline Volatility & & & $8.13 * * *$ & 1.54 & & & & \\
\hline Log (Size) & & & $-14.47 * * *$ & 2.32 & $-13.45^{* * *}$ & 2.06 & $-12.94 * * *$ & 2.75 \\
\hline Altman 's Z Score & & & & & $2.57 * * *$ & 0.59 & & \\
\hline Rated Indicator & & & 6.44 & 5.01 & 0.88 & 5.04 & & \\
\hline Rating & & & & & & & $-5.4 * *$ & 2.23 \\
\hline Intercept & $761.5 * * *$ & 48.79 & $636.01 * * *$ & 49.07 & $720.87 * * *$ & 48.49 & $747.5 * * *$ & 59.98 \\
\hline \multicolumn{9}{|l|}{ Covenant Fixed Effect } \\
\hline \multicolumn{9}{|l|}{ Year Fixed Effect } \\
\hline Adjusted R-Square & 0.22 & & 0.28 & & 0.25 & & 0.24 & \\
\hline Number of Observations & 1,656 & & 1,656 & & 1,656 & & 1,045 & \\
\hline
\end{tabular}

\footnotetext{
$* * *, * *$, and $*$ indicate statistical significance at the $0.01,005$, and 0.10 level
} 
Table 11: Regression Tests, Marginal Effects Analysis. The unit of observation is a loan package. The dependent variable is the difference between the spreads of loans with and without a PPC within one package, and the right-hand side variables are differences in PPC and covenant dummies and loan characteristics. The sample includes all the loans in the Deal Scan sample during 1994-2010 which belong to non-financial, non-utility US firms with available accounting and stock price information, conditioning on having at least a loan with a PPC and a loan without one within the same loan package.

\begin{tabular}{|c|c|c|c|c|c|c|c|c|c|c|c|c|}
\hline \multirow[t]{2}{*}{ Variable } & Estimate & StdErr & Estimate & StdErr & Estimate & StdErr & Estimate & StdErr & Estimate & StdErr & Estimate & StdErr \\
\hline & \multicolumn{2}{|c|}{ Model (1) } & \multicolumn{2}{|c|}{ Model (2) } & \multicolumn{2}{|c|}{ Model (3) } & \multicolumn{2}{|c|}{ Model (4) } & \multicolumn{2}{|c|}{ Model (5) } & \multicolumn{2}{|c|}{ Model (6) } \\
\hline$\triangle \mathrm{ACCPPC}$ & $-37.29 * * *$ & 8.62 & $-39.32 * * *$ & 47.31 & & & & & & & & \\
\hline$\triangle \mathrm{INCPPC}$ & & & & & $-23.99 * *$ & 11.21 & $-24.53 * *$ & 11.52 & & & & \\
\hline$\triangle \mathrm{DECPPC}$ & & & & & & & & & $14.98 * * *$ & 5.52 & $9.70^{*}$ & 5.73 \\
\hline$\Delta \log$ (Facility Amount) & & & $-15.30 * * *$ & 2.54 & & & $-14.97 * * *$ & 2.56 & & & $-14.55^{* * *}$ & 2.58 \\
\hline$\Delta$ Loan Maturity & & & 0.13 & 0.12 & & & $0.34 * * *$ & 0.11 & & & $0.32 * * *$ & 0.11 \\
\hline$\Delta$ Secured & & & -1.61 & 9.79 & & & -7.48 & 9.74 & & & -7.01 & 9.75 \\
\hline$\Delta$ Revolver & & & $-16.80 * * *$ & 4.89 & & & $-15.94 * * *$ & 4.91 & & & $-14.63^{* * *}$ & 4.94 \\
\hline Intercept & $-14.62 *$ & 8.12 & 29.23 & 47.31 & $-46.17 * * *$ & 2.83 & -9.13 & 46.61 & $-56.22 * * *$ & 4.16 & -14.42 & 46.71 \\
\hline Year Fixed Effect & No & & Yes & & No & & Yes & & No & & Yes & \\
\hline Adjusted R-Square & 0.02 & & 0.04 & & $2 \mathrm{E}-3$ & & 0.03 & & $4 \mathrm{E}-3$ & & 0.03 & \\
\hline Number of Observations & 1,476 & & 1,438 & & 1,476 & & 1,438 & & 1,476 & & 1,438 & \\
\hline
\end{tabular}

$* * *, * *$, and $*$ indicate statistical significance at the $0.01,005$, and 0.10 level 
Table 12: Loan Announcement Returns and Decreasing PPCs. The table presents results that explain the difference in loan announcement returns between loans with a decreasing performance pricing covenants and loans with increasing performance pricing covenants. The sample includes loans in the Deal Scan sample during 1994-2010. The borrowers are non-financial non-utility US firms with available accounting and stock price information that either have a decreasing PPC or an increasing PPC. Loan announcement dates are hand searched at Factiva news archives within one month of loan inception date. Announcement returns are calculated as cumulative market adjusted returns at the ($1,+1)$ trading-day window centered on loan announcements date. Detailed definitions of the explanatory variables can be found in Table 3 .

\begin{tabular}{|c|c|c|c|c|c|}
\hline Explanatory Variables & (1) & (2) & (3) & (4) & (5) \\
\hline Dummy: Decreasing Covenant & $\begin{array}{l}0.023 * * * \\
(0.004)\end{array}$ & $\begin{array}{l}0.015^{* * * *} \\
(0.005)\end{array}$ & $\begin{array}{l}0.019 * * * \\
(0.006)\end{array}$ & $\begin{array}{l}0.019 * * * \\
(0.006)\end{array}$ & $\begin{array}{l}0.018 \text { *** } \\
(0.006)\end{array}$ \\
\hline ROA & & $\begin{array}{l}-0.011 \\
(0.083)\end{array}$ & $\begin{array}{l}-0.016 \\
(0.084)\end{array}$ & & \\
\hline Leverage & & $\begin{array}{l}0.007 \\
(0.008)\end{array}$ & $\begin{array}{l}0.003 \\
(0.009)\end{array}$ & & \\
\hline Market to Book & & $\begin{array}{l}-0.001 \\
(0.002)\end{array}$ & $\begin{array}{l}-0.002 \\
(0.002)\end{array}$ & & \\
\hline Volatility & & $\begin{array}{l}0.003^{*} \\
(0.002)\end{array}$ & $\begin{array}{l}0.003 \\
(0.002)\end{array}$ & & \\
\hline $\log ($ Size $)$ & & $\begin{array}{l}-0.005^{* * * *} \\
(0.002)\end{array}$ & $\begin{array}{l}-0.003 \\
0.2949\end{array}$ & & \\
\hline Altman's Z Score & & & & $\begin{array}{l}-0.001 * \\
(4.9 \mathrm{E}-4)\end{array}$ & \\
\hline Rated Indicator & & $\begin{array}{l}-0.003 \\
(0.005)\end{array}$ & $\begin{array}{l}-0.003 \\
(0.005)\end{array}$ & $\begin{array}{l}-0.003 \\
(0.005)\end{array}$ & \\
\hline Rating & & & & & $\begin{array}{l}-4.8 \mathrm{E}-4 \\
(0.002)\end{array}$ \\
\hline Log (All-in-Drawn Spread) & & & $\begin{array}{l}-0.006 \\
(0.005)\end{array}$ & $\begin{array}{l}-0.002 \\
(0.005)\end{array}$ & $\begin{array}{l}-0.005 \\
(0.005)\end{array}$ \\
\hline Log (Facility Amount) & & & $\begin{array}{l}-0.004 \\
(0.003)\end{array}$ & $\begin{array}{l}-0.007 * * * \\
(0.002)\end{array}$ & $\begin{array}{l}-0.005 * * \\
(0.002)\end{array}$ \\
\hline Loan Maturity (months) & & & $\begin{array}{l}1.2 \mathrm{E}-5 \\
(1.0 \mathrm{E}-3)\end{array}$ & $\begin{array}{l}1.1 \mathrm{E}-6 \\
(9.9 \mathrm{E}-5)\end{array}$ & $\begin{array}{l}-1.1 \mathrm{E}-5 \\
(1.1 \mathrm{E}-4)\end{array}$ \\
\hline Syndicated & & & $\begin{array}{l}0.012 \\
(0.012)\end{array}$ & $\begin{array}{l}0.012 \\
(0.331)\end{array}$ & $\begin{array}{l}0.004 \\
(0.015)\end{array}$ \\
\hline Secured & & & $\begin{array}{l}0.002 \\
(0.006)\end{array}$ & $\begin{array}{l}0.004 \\
(0.546)\end{array}$ & $\begin{array}{l}0.007 \\
(0.006)\end{array}$ \\
\hline Missing Secured Status & & & $\begin{array}{l}-0.010 \\
(0.008)\end{array}$ & $\begin{array}{l}-0.011 \\
(0.144)\end{array}$ & $\begin{array}{l}-0.011 \\
(0.007)\end{array}$ \\
\hline Revolver & & & $\begin{array}{l}-0.005 \\
(0.359)\end{array}$ & $\begin{array}{l}-0.004 \\
(0.467)\end{array}$ & $\begin{array}{l}-0.004 \\
(0.005)\end{array}$ \\
\hline Intercept & $\begin{array}{l}-0.022 \\
(0.019)\end{array}$ & $\begin{array}{l}0.027 \\
(0.034)\end{array}$ & $\begin{array}{l}0.104 * \\
(0.059)\end{array}$ & $\begin{array}{l}0.121^{* *} \\
(0.057)\end{array}$ & $\begin{array}{l}0.115^{*} \\
(0.060)\end{array}$ \\
\hline Year Fixed Effect & Yes & Yes & Yes & Yes & Yes \\
\hline Adjusted R-Square & 0.05 & 0.07 & 0.06 & 0.06 & 0.05 \\
\hline Number of Observations & 943 & 943 & 943 & 943 & 699 \\
\hline
\end{tabular}


Table 13: Regression Tests, Ex post Operating Performance. The relationship between the inclusion of a decreasing performance pricing covenants and ex post (industry-adjusted) changes in the borrower's return on investment (ROA) and Altman's Z-Score during years that start at the end of the deal quarter is estimated. The sample includes all nonfinancial non-utility US borrowers in the Deal Scan sample who have received a loan during 1994-2010. The sample is then restricted to borrowers whose loans include either an interest increasing PPC or an interest decreasing PPC.

\begin{tabular}{|c|c|c|c|c|c|c|c|c|}
\hline Panel A: ROA & \multicolumn{4}{|c|}{ Change in ROA (12 Month) } & \multicolumn{4}{|c|}{ Change in ROA (24 Month) } \\
\hline Explanatory Variables & (1) & (2) & (3) & (4) & (5) & (6) & (7) & (8) \\
\hline Dummy: Decreasing Covenant & $\begin{array}{l}0.006 * * * \\
(0.002)\end{array}$ & $\begin{array}{l}0.005 * * \\
(0.002)\end{array}$ & $\begin{array}{l}0.005 * * \\
(0.002)\end{array}$ & $\begin{array}{l}0.004 * \\
(0.002)\end{array}$ & $\begin{array}{l}0.007 * * * \\
(0.002)\end{array}$ & $\begin{array}{l}0.005^{* *} \\
(0.002)\end{array}$ & $\begin{array}{l}0.006 * * * \\
(0.002)\end{array}$ & $\begin{array}{l}0.005 * * \\
(0.002)\end{array}$ \\
\hline $\begin{array}{l}\text { Borrower Risk Controls } \\
\text { (Ex-Ante Profitability, } \\
\text { Leverage, Market to Book } \\
\text { and Volatility, Rated Status) }\end{array}$ & Yes & & & Yes & & & Yes & \\
\hline $\begin{array}{l}\text { Borrower Risk Controls } \\
\text { (Ex-Ante Altman Z-Score, } \\
\text { Rated Status) }\end{array}$ & & Yes & & & Yes & & & Yes \\
\hline $\begin{array}{l}\text { Borrower Risk Control } \\
\text { (Ex-Ante Credit Rating) }\end{array}$ & & & Yes & & & Yes & & \\
\hline Year Fixed Effect & Yes & Yes & Yes & Yes & Yes & Yes & Yes & Yes \\
\hline Adjusted R-Square & 0.01 & 0.02 & 0.01 & $2 \mathrm{E}-3$ & 0.02 & 0.04 & 0.02 & 0.01 \\
\hline Number of Observations & 3,384 & 3,384 & 3,384 & 2,458 & 3,042 & 3,042 & 3,042 & 2,338 \\
\hline
\end{tabular}

Change in Z-Score (12 Month)

Change in Z-Score (24 Month)

Panel B: Altman Z-Score

\begin{tabular}{|c|c|c|c|c|c|c|c|c|}
\hline Explanatory Variables & (1) & (2) & (3) & (4) & (5) & (6) & (7) & (8) \\
\hline Dummy: Decreasing Covenant & $\begin{array}{l}0.557 * * * \\
(0.179)\end{array}$ & $\begin{array}{l}0.290 * \\
(0.185)\end{array}$ & $\begin{array}{l}0.231 \\
(0.177)\end{array}$ & $\begin{array}{l}0.333^{*} \\
(0.186)\end{array}$ & $\begin{array}{l}0.580 * * * \\
(0.222)\end{array}$ & $\begin{array}{l}0.167 \\
(0.228)\end{array}$ & $\begin{array}{l}0.127 \\
(0.214)\end{array}$ & $\begin{array}{l}0.306 \\
(0.235)\end{array}$ \\
\hline $\begin{array}{l}\text { Borrower Risk Controls } \\
\text { (Ex-Ante Profitability, } \\
\text { Leverage, Market to Book } \\
\text { and Volatility, Rated Status) }\end{array}$ & Yes & & & Yes & & & Yes & \\
\hline $\begin{array}{l}\text { Borrower Risk Controls } \\
\text { (Ex-Ante Altman Z-Score, } \\
\text { Rated Status) }\end{array}$ & & Yes & & & Yes & & & Yes \\
\hline $\begin{array}{l}\text { Borrower Risk Control } \\
\quad \text { (Ex-Ante Credit Rating) }\end{array}$ & & & Yes & & & Yes & & \\
\hline Year Fixed Effect & Yes & Yes & Yes & Yes & Yes & Yes & Yes & Yes \\
\hline Adjusted R-Square & 0.01 & 0.03 & 010 & 0.01 & 0.01 & 0.06 & 0.15 & 0.01 \\
\hline Number of Observations & 3,298 & 3,298 & 3,298 & 2,390 & 2,947 & 2,947 & 2,947 & 2,262 \\
\hline
\end{tabular}

$* * *, * *$, and $*$ indicate statistical significance at the $0.01,005$, and 0.10 level 